\title{
Integration of new and revised chronological data to constrain the terrace evolution of the Danube River (Gerecse Hills, Pannonian Basin)
}

\author{
Zs Ruszkiczay-Rüdiger ${ }^{\mathrm{a}, ~ *}$, G. Csillag, ${ }^{\mathrm{a}, \mathrm{b}}$, L. Fodor ${ }^{\mathrm{b}, \mathrm{c}}$, R. Braucher ${ }^{\mathrm{d}}$, Á. Novothnye, E. Thamó-Bozsóf $^{\mathrm{f}}$, A. Virágg, \\ P. Pazonyig, G. Timár ${ }^{\text {h }}$, ASTER Team \\ ${ }^{a}$ Hungarian Academy of Sciences (MTA), Research Centre for Astronomy and Earth Sciences, Institute for Geological and Geochemical Research, Budaörsi út 45, 1112, Budapest, Hungary \\ ${ }^{\mathrm{b}}$ MTA- ELTE Geological, Geophysical and Space Science Research Group, Pázmány Péter Sétány 1/c, 1117, Budapest, Hungary \\ ${ }^{\mathrm{c}}$ MTA- ELTE Volcanological Research Group, Pázmány Péter sétány 1/c, 1117, Budapest, Hungary \\ ${ }^{\mathrm{d}}$ Aix-Marseille Univ., CNRS, IRD, Coll. France, UM 34 CEREGE, Technopôle de L'Environnement Arbois-Méditerranée, BP80, 13545, Aix-en-Provence, France \\ e Department of Physical Geography, Eötvös University (ELTE), Pázmány P. sétány 1/c, 1117, Budapest, Hungary \\ ${ }^{\mathrm{f}}$ Mining and Geological Survey of Hungary, Stefánia út 14, 1143, Budapest, Hungary \\ ${ }^{g}$ MTA-MTM-ELTE Research Group for Paleontology, Pázmány Péter sétány 1/c, 1117, Budapest, Hungary \\ ${ }^{\mathrm{h}}$ Department of Geophysics and Space Science, Eötvös University (ELTE), Pázmány P. sétány 1/c, 1117, Budapest, Hungary
}

\section{A R T I C L E I N F O}

\section{Keywords:}

Quaternary

Cosmogenic nuclides

Luminescence

Paleontology

$\mathrm{U} / \mathrm{Th}$ dating

River terraces

\begin{abstract}
A B S T R A C T
Terrace ages deduced from diverse geochronological records yielded inconsistent data in the Danube valley in Hungary. The problem of discrepancies in the different chronological datasets has to be resolved before the Quaternary tectonic and climatic processes leading to valley incision and terrace formation may be properly evaluated.

To establish a more robust chronology of the Danube valley in Hungary, new cosmogenic nuclide- $\left({ }^{10} \mathrm{Be}\right.$ depth profiles, ${ }^{26} \mathrm{Al} /{ }^{10} \mathrm{Be}$ burial durations and burial depth profile) and luminescence-based (pIRIR ${ }_{290}$ ) terrace ages were acquired and compared to revised paleontological and published U/Th and magnetostratigraphic data. All the applied geo-chronometers led to concordant terrace ages, with the exception of the U/Th method applied on travertine deposits covering terraces. U/Th ages predating the last interglacial manifest a bias towards younger ages, and so they were ignored in relation to the quantification of terrace ages. As a result, terrace ages from the Late Pliocene to Late Pleistocene were settled. With regard to data from the Middle Pleistocene onwards, the combination of diverse methodologies led to a tighter bracketing of terrace ages than would be possible using a single dating method. The modelling of cosmogenic ${ }^{26} \mathrm{Al}$ and ${ }^{10} \mathrm{Be}$ concentrations enabled to derive surface denudation rates and their combination with paleontological data also allowed us to decide between diverse landscape evolution scenarios.
\end{abstract}

\section{Introduction}

River terraces may develop as a complex response of tectonic uplift/ base level drop and climate change. Terrace aggradation and abandonment by the river may be triggered by climate change and tectonic uplift or by the interaction of both. Numerical terrace-chronological data are of first order importance to decipher the role of climatic forcing and to quantify the uplift rate at a certain location.

Within the Pannonian Basin System the Danube River is the only river connecting the subsiding sub-basins of the Danube Basin (DB) and Great Hungarian Plain (GHP) by cutting through the elevated basement unit of the Transdanubian Range (TR) (Fig. 1A and B). Vertical deformation is indicated by the ongoing accumulation of alluvial sediments in the still subsiding lowlands (Horváth et al., 1988; Horváth and Cloetingh, 1996). In TR several offset geomorphic levels refer to the uplift of these areas (Pécsi, 1959; Pécsi et al., 1984; Gábris, 1994; Kaiser, 1997; Ruszkiczay-Rüdiger et al., 2005a, 2011). A better understanding of the incision history of the Danube River is possible by the age determination of its terraces. Our study area, the Gerecse Hills is at the northwestern part of the TR.

Several relative and some numerical chronological studies were carried out in the area to date river terraces (Halaváts, 1898; Hennig et

\footnotetext{
* Corresponding author.

Email address: rrzsofi@geochem.hu (Z. Ruszkiczay-Rüdiger)
} 


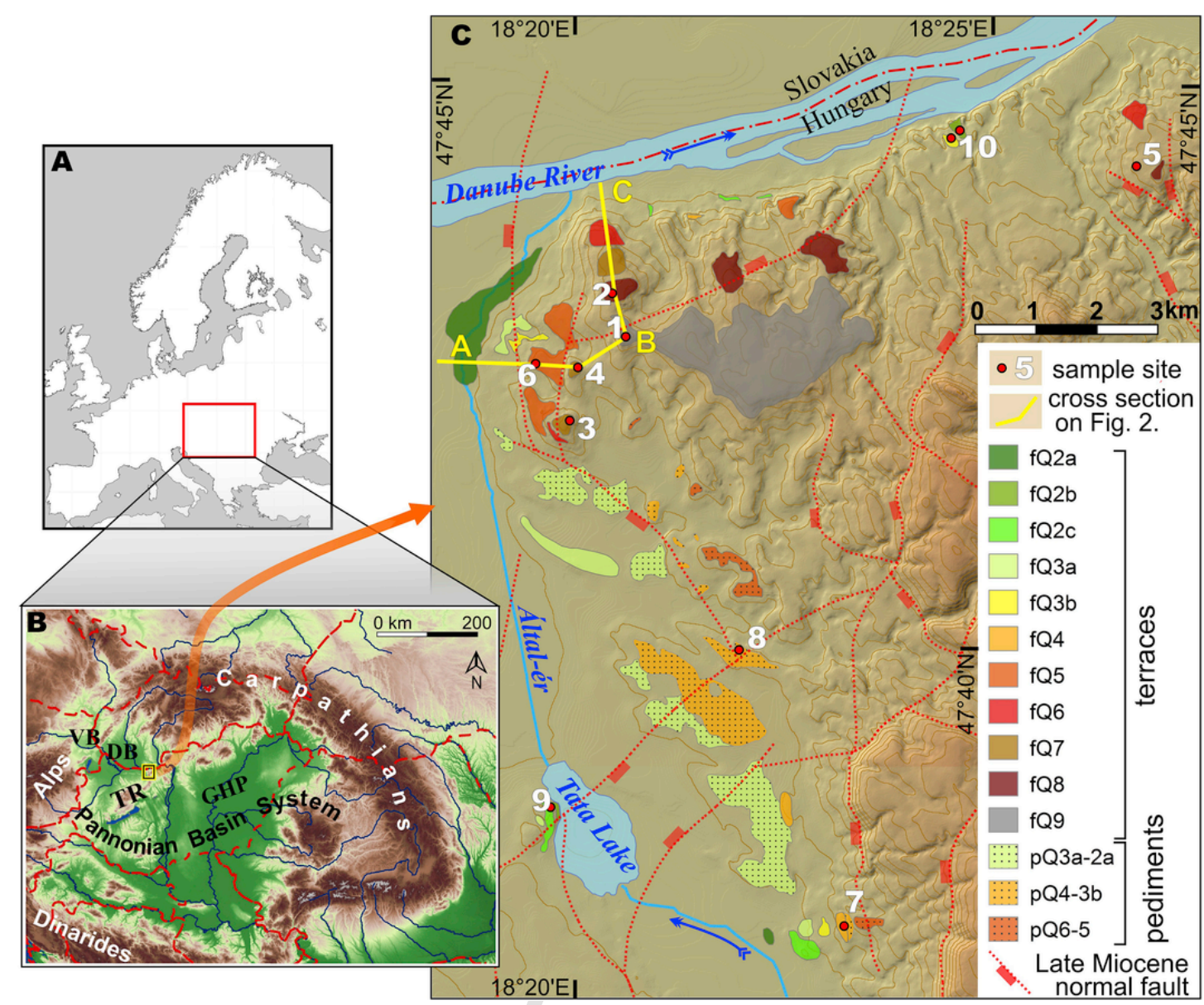

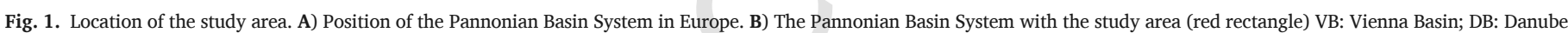

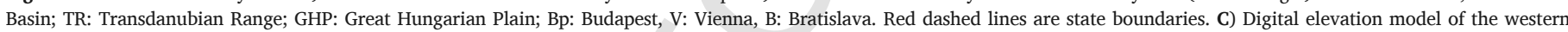

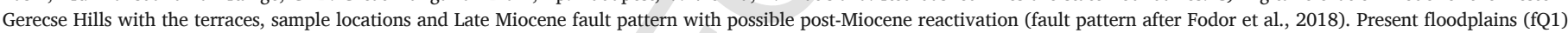

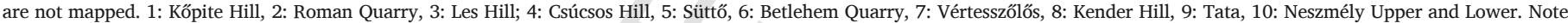

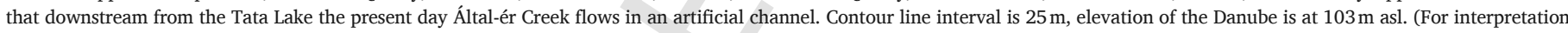
of the references to colour in this figure legend, the reader is referred to the Web version of this article.)

al., 1983; Kele, 2009; Kordos, 1994; Kretzoi, 1953; Lantos, 2004; Osmond, 1990; Ruszkiczay-Rüdiger et al., 2005b, 2016), however, their results are controversial, and invoke the need for novel age determinations at several levels of the terrace staircase.

Numerous studies have delivered valuable chronological datasets concerning river terraces and river incision using various dating methods (Rixhon et al., 2017). The advance of the use of in situ-produced cosmogenic radionuclides (CRN) led to the age determination of terraces either by the cosmic-ray exposure age dating of terraces (Siame et al., 2004; Rixhon et al., 2011; Antón et al., 2012; Stange et al., 2013, 2014; Schaller et al., 2016), or the determination of burial duration of thick terrace sequences (Erlanger et al., 2016; Bender et al., 2016; Çiner et al., 2015; Zhao et al., 2016) or of sediments trapped in related cave systems (Häuselmann et al., 2007a; Wagner et al., 2010; Rixhon et al., 2014). Several studies have addressed river incision through the joint application of luminescence and cosmogenic nuclides (Anders et al., 2005; DeLong and Arnold, 2007; Guralnik et al., 2011; Viveen et al., 2012; Ruszkiczay-Rüdiger et al., 2016; Braumann et al., 2018).

Different age determination methods (e.g. CRN combined with luminescence, U/Th, paleontology or $\mathrm{K}-\mathrm{Ar}$ and ${ }^{40} \mathrm{Ar} /{ }^{39} \mathrm{Ar}$ ) of terrace- and/ or terrace-covering formations have yielded convergent results (Antoine et al., 2007; Guralnik et al., 2011; Viveen et al., 2012; Thompson et al., 2018; Rixhon et al., 2011; Zhao et al., 2016; Braumann et al., 2018), while on other occasions diverse approaches have led to conflicting terrace ages (Schaller et al., 2016). The problem of inconsistencies in terrace ages needs to be resolved before evaluating the tectonic and climatic processes involved in valley incision and terrace formation.

The present study aims to set up a robust terrace chronology in the Danube valley as it crosses the northern-central part of the Pannonian Basin with the use of multiple age determination methods. The study area, the western Gerecse Hills was selected because the terrace staircase is at its most complete in this area, bounded by the Danube and its tributary the Által-ér creek. The study area may therefore be considered a suitable location for the revision of the terrace system of the Hungarian Danube valley.

Due to the presence of sand and gravel-rich terrace sediments and the expected time-span from Late-Pleistocene to Pliocene times, novel terrace ages are obtained using $\mathrm{CRN}\left({ }^{10} \mathrm{Be}\right.$ depth profiles, ${ }^{26} \mathrm{Al} /{ }^{10} \mathrm{Be}$ burial dating) for the higher and older horizons, and Infrared Stimulated Luminescence (IRSL) for the lower terraces falling within the datable time range of this method. The middle terraces are addressed by both methods for more robust geochronological data.

For a better understanding of the Quaternary landscape evolution, the analysis of the ${ }^{26} \mathrm{Al} /{ }^{10} \mathrm{Be}$ ratios are used also for the differentiation between primary terrace sediments and re-deposited gravels. Besides, a most probable post-depositional landscape evolution scenario for the highest terrace level is outlined by the modelling of ${ }^{26} \mathrm{Al} /{ }^{10} \mathrm{Be}$ concentrations along a burial depth profile. 
In addition to the numerical age determinations, a thorough nomenclatural and taxonomic revision of the terrace-related faunas was carried out, and the revised faunas were set in an up-to date numerical age context.

The new terrace ages are then compared to published magnetostratigraphic and U/Th data of travertines associated with terraces (Latham and Schwarcz, 1990; Lantos, 2004; Hennig et al., 1983; Schwartz and Latham, 1990; Osmond, 1990; Kele, 2009; Sierrallta et al., 2010). Such comparisons allow the discussion of the suitability and limitations of these methods for the quantification of terrace ages and river incision in an updated geological, geomorphological and geochronological timeframe.

\section{Geological and geomorphological setting}

The Early- to Middle Miocene extension and the subsequent Late Miocene thermal subsidence of the Pannonian Basin was followed by neotectonic basin inversion. This phase is characterised by ongoing accelerated differential vertical deformation, mainly in the form of large-wavelength folds, blind reverse faults and transpressional structures. Reactivation of normal faults was also possible if they were oriented parallel to the main horizontal stress axes at ca. NE-SW in the study area (Horváth and Cloetingh, 1996; Fodor et al., 2005; Dombrádi et al., 2010).

The Transdanubian Range (TR) in the western Pannonian Basin is a topographically elevated NW-SE trending ridge, 300-600 $\mathrm{m}$ higher than the surrounding lowlands and low hilly areas, with elevations of up to $756 \mathrm{~m}$ a.s.l. (Fig. 1B).

The Gerecse Hills lie on the northern side of the TR, to the south of the incised Danube River (Fig. 1B and C). Triassic carbonate rocks are exposed in the central part of the Gerecse Hills and are covered by Paleogene to Neogene siliciclastic rocks on the northern and western flanks. The previous deformation phases juxtaposed the Mesozoic and Late Miocene rocks along - N-S to NE-SW trending normal or oblique-slip faults (Fodor et al., 2018). Along the main contacts deformation of Miocene rocks are clearly exposed, while away from these fault scarps displacements are mostly postulated on the basis of boreholes. The recognition of neotectonic reactivation of the Late Miocene structures, or alternatively, formation of new, neotectonic elements are hampered by poor outcrop conditions of Plio-Quaternary sediments.

However, there are several geomorphic evidences on the Quaternary deformation of the Pannonian Basin (Pécsi et al., 1984; Fodor et al., 2005. Ruszkiczay-Rüdiger et al., 2009). The uplifting units of the TR separate the subsiding sub-basins of the Danube Basin and the Great Hungarian Plain from each other (Fig. 1B). The Danube is the only river, which cuts through the uplifting pre-Quaternary formations of the TR. Its terraces at several elevations with concave geometry along the river have been interpreted as indicators of subsequent stages of uplift-driven river incision with different uplift rates along the river (Pécsi, 1959; Gábris, 1994; Gábris and Nádor, 2007; Ruszkiczay-Rüdiger et al., 2005a, 2016).
In the Gerecse Hills the highest geomorphologic horizons are Cenozoic planation surfaces (Kaiser, 1997). The Danube and its tributary, the Által-ér have incised into Upper Miocene siliciclastic rocks and their valleys are characterised by a coherent system of Late Pliocene - Quaternary pediment surfaces and Plio-Quaternary river terraces, the main objects of this study (Fig. 1C). The pediments are eroded surfaces of Neogene siliciclastic sediments, which may be covered by sheet-wash deposits in variable thickness and occasionally by alluvial fans of the small tributaries and/or eolian sediments (Csillag et al., 2018).

\subsection{Terraces of the Gerecse Hills}

Formerly, the terrace chronology of the Danube in Hungary was based mostly on geomorphological, sedimentological and paleonthological data. Terraces were numbered from the lowest to the highest, using increasing Roman numbers as they became older (tI- tVII; Pécsi, 1959; Gábris, 1994; Ruszkiczay-Rüdiger et al., 2005a, 2016 and references therein). However, our novel age data together with the geomorphological and geological observations of Csillag et al. (2018) have enabled a challenge to be made to the old system. In this study, terraces are distinguished from the "traditional" terrace system by the prefix "fQ" (fluvial Quaternary) and the use of Arabic numbers. The level fQ1 is the recent floodplain, and not considered as a terrace. Terraces fQ2 and fQ3 were divided into three and two sub-levels (fQ2c-fQ2b-fQ2a and fQ3b-fQ3a, respectively, Fig. 1).

The base level of the Danube lies at $103 \pm 1 \mathrm{~m}$ a.s.l. and 11 terrace levels form a staircase up to $\sim 180 \mathrm{~m}$ above the river (fQ2a-fQ9; Fig. 1). On the western margin of the Gerecse Hills, the terraces have developed in the valley carved by the Által-ér creek, a tributary of the Danube (Fig. 1).

The terrace deposits in the study area consist of cross-bedded sandy gravels and gravelly sands of variable thickness, from a few centimetres up to $\sim 20 \mathrm{~m}$. The terraces are frequently covered by travertine deposited by lukewarm karstwater springs upwelling from the underlying carbonate rocks (Fig. 2; Schréter, 1953; Scheuer and Schweitzer, 1988; Schweitzer and Scheuer, 1995; Kele, 2009; Török et al., 2017) and by loess (Novothny et al., 2011; Csillag et al., 2018). Fluvial sediments of considerable thickness have been preserved where they were protected by an overlying travertine unit (Figs. 2 and 3).

In the Gerecse Hills, over 50 occurrences of travertine at variable elevations have been identified, mostly located on the northern and western margins of the area. Despite the fact that valley-side and tetarata-type travertines were recognised, travertine formation was generally considered to occur at or close to the base level (Pécsi et al., 1982, 1984; Schweitzer and Scheuer, 1995). Travertines were classified in a way similar to terraces, as a staircase with higher horizons having subsequently older ages $\left(\mathrm{T}_{1}-\mathrm{T}_{10}\right)$ (Schweitzer and Scheuer, 1995). The significance of recent travertine formation is limited, occurring only locally at some lukewarm springs. Currently, travertine thickness ranges from $>40 \mathrm{~m}$ to small, fragmented remnants of a former travertine unit scattered on the surface. The initial total thickness of the travertines is

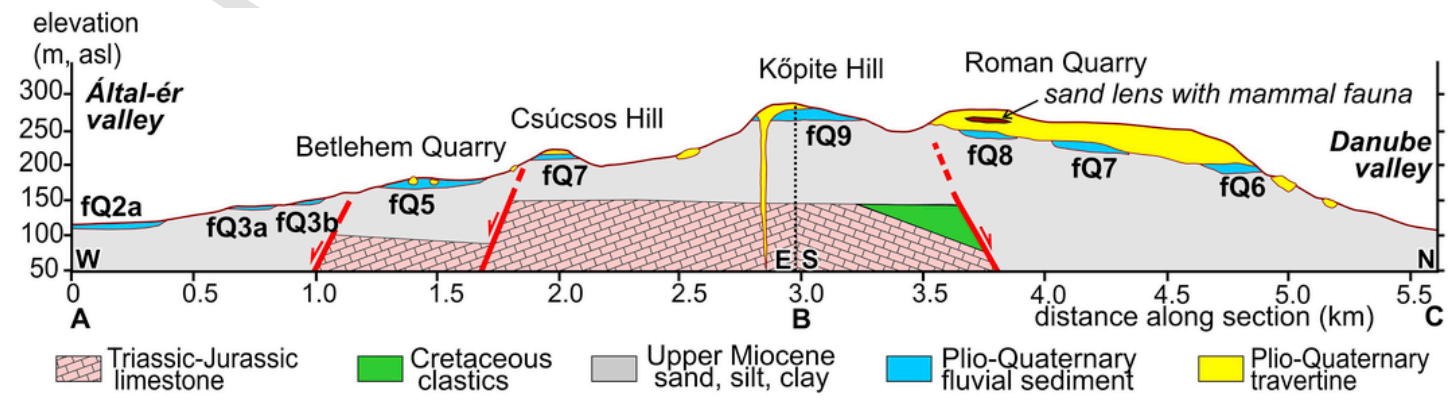

Fig. 2. Simplified cross section of the Gerecse Hills. For location see Fig. 1C. 
Upper terraces (fQ9-7)

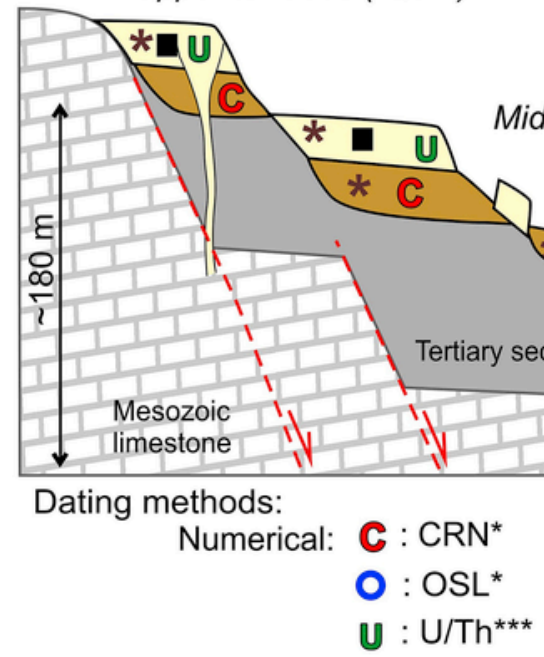

travertine

fluvial terrace

Middle terraces (fQ6-4)

(1) Lower terraces (fQ3-2)

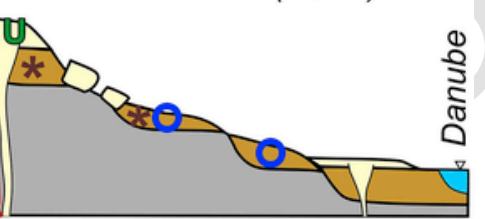

Relative: * : Paleontology**

: Magnetostratigraphy***

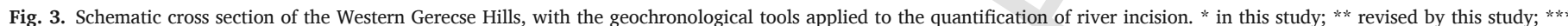
literature data (see details in text). (Note that the cross section is not to scale and the number of terraces is fewer than in the study area).

supposed to have been between 30 and $50 \mathrm{~m}$ (Scheuer and Schweitzer, 1988; Kele, 2009; Török et al., 2017; Csillag et al., 2018). Travertine units are frequently affected by gravitational sliding, with blocks of 1-10 m size displaced downslope from their original position (Schréter, 1953; Csillag et al., 2018).

\section{Sampling strategy and methodology}

In an earlier study on Danube terraces, Ruszkiczay-Rüdiger et al. (2016) showed that for river terraces younger than 200-300 ka, IRSL was more suitable as a dating method than CRN due to the likelihood of effective surface denudation. In addition, the number of samples required to perform luminescence dating is smaller than that for a CRN depth profile. Therefore, in this study, lower terraces were only sampled for IRSL dating. With regard to higher surfaces, whose ages may be close to the upper limit of the datable time range of the luminescence method, these were sampled for both IRSL and CRN dating to provide the best possible time constraints on the terrace formation (DeLong and Arnold, 2007; Guralnik et al., 2011; Viveen et al., 2012). The highest horizons were sampled for CRN dating only.

Sample locations were selected on the basis of a detailed geomorphological and geological mapping (for details refer to Csillag et al., 2018). The mapped terraces are presented in Fig. 1C.

In situ-produced cosmogenic ${ }^{10} \mathrm{Be}$ exposure age determination relies on samples collected along depth profiles at two locations (Betlehem Quarry, Kender Hill; $\mathrm{n}=14$ ). Burial duration determination of the fluvial sediments relies on the ${ }^{26} \mathrm{Al} /{ }^{10} \mathrm{Be}$ nuclide pair ratio measured at three sites (Süttô, Les Hill, Kópite; $\mathrm{n}=12$ ). Post-Infrared Infrared Stimulated Luminescence ( IRIR $_{290}$ ) age determination was performed at four outcrops (Betlehem Quarry, Kender Hill, and the Neszmély Upper and Lower sandpits, $\mathrm{n}=10$ ).

CRN samples were collected using a shovel from the previously cleaned outcrop in the case of loose material and hammer and chisel when travertine-cemented gravel was sampled. At one location CRN sampling was carried out from a drilling (Kőpite Hill). IRSL samples were taken by pushing metal or light-excluding dark PVC tubes into the previously cleaned wall. The position and elevation of the samples were recorded in the field using a hand-held GPS device (WGS84 reference datum) and cross referenced with 1:10 000 topographic maps (Table 1).

To best constrain the terrace ages of the Gerecse Hills, the data acquired in this study are compared with published U/Th and magne- tostratigraphic ages of travertines covering the terraces and therefore providing a minimum age for terrace formation. Paleontological data from the terraces and from the travertine were revised to decide if the numerical and relative age constraints support each other, and if not, to examine any potential reasons for discrepancies. The geochronological relationship between diverse numerical ages provided by different methods is shown in Fig. 3.

\subsection{Cosmogenic nuclides}

Several distinct methodologies using CRN are suitable for determining the age of clastic sediments (e.g. Gosse and Phillips, 2001; Dunai, 2010). Both exposure age determination using ${ }^{10} \mathrm{Be}$ depth profiles and burial age determination using the ${ }^{26} \mathrm{Al}$ and ${ }^{10} \mathrm{Be}$ nuclide pair are applied in this study. These approaches depend on the local sedimentological and geological setting of the outcrop. In the following, the methods of age determination using CRN depth profiles and burial durations are described, while the theory and technical details of age determination and parameters used throughout this study are described in Supplement 1.1.

\subsubsection{Exposure age dating along ${ }^{10} \mathrm{Be}$ depth profiles}

It has been demonstrated that the evolution of the concentration of a single cosmogenic nuclide along a depth profile makes possible to constrain both the exposure duration and the denudation rate of a relief relying on the well-known relationships dependent on the respective attenuation lengths linking spallogenic and muonic production rates to depth (Anderson et al., 1996; Siame et al., 2004; Braucher et al., 2009; Hidy et al., 2010; Rixhon et al., 2011, 2014; Ruszkiczay-Rüdiger et al., $2011,2016)$. If the exposure duration has not been long enough to reach steady state at depth (muonic production), the evolution of the CRN concentration with depth will allow us to arrive at a unique solution of exposure duration and denudation rate and determine the inherited CRN concentration (the concentration accumulated during a previous surface exposure and denudation episode).

If the exposure duration has been long enough to reach a steady state at depth (muonic production), a time averaged denudation rate and a minimum exposure duration corresponding to the minimum time necessary to reach the measured steady-state concentrations (integration time; Lal, 1991) can be calculated (Lal, 1991; Matsushi et al., 2006; Braucher et al., 2009; Hidy et al., 2010; Ruszkiczay-Rüdiger et al., 2016). Exposure duration determination based on depth profiles re- 
Table 1

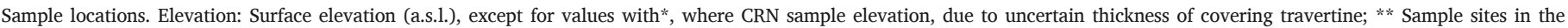
Által-ér valley; pal: revised paleontology.

\begin{tabular}{|c|c|c|c|c|c|c|}
\hline Location & Sample & Latitude (DD) & Longitude (DD) & Elevation. (m) & Terrace level & Method \\
\hline Kôpite & Dszt-02 to -15 & 47.7121 & 18.3358 & 286 & fQ9 & CRN burial + pal \\
\hline \multicolumn{7}{|l|}{ Süttő } \\
\hline Gazda Quarry & Dan13-01 & 47.7369 & 18.4476 & $218 *$ & fQ7? & CRN burial + pal \\
\hline Gazda Quarry & Dan13-02 & 47.7357 & 18.4469 & $215^{*}$ & fQ7? & CRN burial + pal \\
\hline Újharaszt Quarry & Süttő-19 & 47.7427 & 18.4517 & 255 & fQ7? & pal \\
\hline Hegyhát Quarry & Süttő-17 & 47.7391 & 18.4474 & 259 & fQ7? & pal \\
\hline Cukor Quarry & Cukor Quarry & 47.7353 & 18.4514 & 278 & fQ8? & pal \\
\hline Roman Quarry & Roman Quarry & 47.7185 & 18.3329 & 280 & fQ8 & pal \\
\hline Les Hill & Dan09-05 to -07 & 47.6998 & 18.3240 & 232 & fQ7 & $\mathrm{CRN}$ burial $+\mathrm{pal}$ \\
\hline Csúcsos Hill & Csúcsos Hill & 47.7076 & 18.3257 & 223 & fQ7 & pal \\
\hline Betlehem Quarry & $\begin{array}{l}\text { Dan08-50 to }-58 ; \\
\text { LUM-2284 to }-2285\end{array}$ & 47.7080 & 18.3165 & 178 & fQ5 & $\begin{array}{l}\text { CRN depth profile }+ \\
\text { IRSL }+ \text { pal }\end{array}$ \\
\hline Vértesszőlős** & Paleolithic site & 47.6262 & 18.3844 & 182 & fQ4 & pal \\
\hline Kender Hill $* *$ & $\begin{array}{l}\text { Dan09-09 to }-13 \\
\text { LUM-2281 to }-2283\end{array}$ & 47.6664 & 18.3610 & 172 & pQ4-3b & $\begin{array}{l}\text { CRN depth profile }+ \\
\text { IRSL }+ \text { pal }\end{array}$ \\
\hline Neszmély Upper & LUM-124.1 to -3 & 47.7417 & 18.4061 & 145 & fQ3b & IRSL \\
\hline Tata** & Porhanyó Quarry & 47.6431 & 18.3205 & 143 & fQ2c & pal \\
\hline Neszmély Lower & LUM-129.1 -2 & 47.7428 & 18.4081 & 120 & fQ2b & IRSL \\
\hline
\end{tabular}

quires that we reach depths at which the muonic production rate is significant, that is, at least $3-4 \mathrm{~m}$. In the study area, this prerequisite regarding terrace material in its original position was only met at two locations (Betlehem Quarry, Kender Hill; Fig. 1).

First, the integration time was determined at each profile location using the maximum denudation rate relevant for the uppermost sample assuming infinite exposure duration. It was then calculated for the deepest samples of the profiles where the time necessary to reach the secular equilibrium between CRN production and decay is longer (Braucher et al., 2003). This provides the time range over which the age of the terrace may be determined using the CRN concentrations measured along a depth profile.

To calculate the most probable exposure age of the sampled terraces, $\chi^{2}$ minimizations were performed using a modified version of the ${ }^{10}$ Be profile simulator 1.2 developed by Hidy et al. (2010), as described by Ruszkiczay-Rüdiger et al. (2016). After preliminary tests, user-defined $\chi^{2}$ cut-off values were defined for each dataset to provide 100000 model solutions for each simulation, thus fulfilling the requirements of Bayesian statistics. For depth profile modelling, the density of sandy gravel was set at as a free parameter, between 1.8 and $2.2 \mathrm{~g} / \mathrm{cm}^{3}$, and considered constant along the profiles.

In case the model age tends to be older than the integration time calculated for the lowest sampled level, only the minimum age of the terrace can be determined (Lal, 1991; Ruszkiczay-Rüdiger et al., 2016).

\subsubsection{Determination of ${ }^{26} \mathrm{Al} /{ }^{10} \mathrm{Be}$ burial duration}

Cosmogenic ${ }^{26} \mathrm{Al}$ and ${ }^{10} \mathrm{Be}$ nuclides accumulate in the selected mineral fraction, in this case quartz, during its surface exposure prior to burial with a well constrained ${ }^{26} \mathrm{Al} /{ }^{10} \mathrm{Be}$ spallogenic production rate ratio of $6.61 \pm 0.52$ (updated from Nishiizumi et al. (1989) by Braucher et al. (2011)). Burial duration determination relies on the differential radioactive decay of these cosmogenic nuclides after the quartz minerals have been shielded from further cosmic irradiation due to their burial under a sufficient thickness of matter.

Because the ${ }^{26} \mathrm{Al}$ concentrations decrease roughly twice faster than the ${ }^{10} \mathrm{Be}$ concentrations, once buried the ${ }^{26} \mathrm{Al} /{ }^{10} \mathrm{Be}$ ratio decreases exponentially, with an apparent half-life of $1.48 \pm 0.01 \mathrm{Ma}$. This allows to estimate burial durations from $\sim 100$ ka to $\sim 5 \mathrm{Ma}$ (Granger and Muzikar, 2001; Granger, 2006).

If the thickness of the overlying material is insufficient $(<15 \mathrm{~m})$ to stop cosmogenic nuclide production, the CRN concentrations measured in the samples will correspond to the sum of the cosmogenic nuclide concentrations accumulated during the previous exposure episode and of the cosmogenic nuclide concentrations accumulated during the burial duration at the sample depth (accounting for radioactive decay for both). This post-burial production increases the CRN concentrations in the rocks at depth, and may therefore lead to an underestimated burial duration, if not accounted for. Accordingly, a burial duration calculated assuming no post-burial production will therefore represent a minimum burial duration estimate (Lebatard et al., 2014).

As long as environmental conditions can be considered as relatively stable over the burial duration (steady denudation) and post-burial CRN production is taken into account, a maximum burial duration can be estimated (Lebatard et al., 2014). If no further geological constraints are present, these bracketing durations can therefore be used to assess the duration of the burial (Granger, 2006). If no independent records suggest a recent change of sample depth (e.g. rapid stripping of a considerable thickness of the overlying material), the latter model accounting for steady denudation and post-burial CRN accumulation usually provides more realistic burial duration estimates.

\subsection{Luminescence dating}

As was the case with cosmogenic nuclides, the applied methods of luminescence age determination will be described here, while the methodological bases and parameters used throughout this study can be found in Supplement 1.2.

\subsubsection{Age determination using the $\operatorname{PIRIR}_{290}$ technique}

In this study, pIRIR ${ }_{290}$ dating was applied to K-feldspar in cases in which the expected age of the sediments of interest was estimated to be potentially out of the range of the quartz blue light stimulated luminescence dating method. The pIRIR $_{290}$ measurements were made using Risø TL/OSL automatic readers with a calibrated ${ }^{90} \mathrm{Sr} /{ }^{90} \mathrm{Y}$ beta source at the Institute of Geography and Geology of Eötvös University, Budapest (ELTE) and at the Mining and Geological Survey of Hungary (MBFSZ, formerly the Geological and Geophysical Institute of Hungary). According to the grain size of the sediments, coarse-grain K-feldspar fractions either between 100 and 150, 150 and 200, or between 250 and $300 \mu \mathrm{m}$ were measured on small and medium aliquots using post-IR elevated temperature IRSL (Buylaert et al., 2009; Thiel et al., 2011, 2012). This Single-Aliquot Regenerative-dose (SAR) protocol 
contains $320^{\circ} \mathrm{C}$ preheat for $60 \mathrm{~s}$, IR stimulation and measurement first for $200 \mathrm{~s}$ at $50^{\circ} \mathrm{C}$, then for $200 \mathrm{~s}$ at $290^{\circ} \mathrm{C}$ (pIRIRSL 290 signal), illumination for 100 sat $325^{\circ} \mathrm{C}$ in the last step of each cycle beside the test dose and different regeneration doses.

Dose-response curves were fitted using a single saturation exponential function. If the pIRIR ${ }_{290}$ signal of a sample was saturated, only the minimum age was calculated, based on the $2 * \mathrm{D}_{0}$ (dose level characteristic of the dose-response curve) value from a single exponential growth curve corresponding to about $86 \%$ of saturation (Wintle and Murray, 2006; Murray et al., 2014). In the case of the unsaturated samples, the measured aliquots were accepted if their test dose error was $<10 \%$, recuperation $<5 \%$, recycling ratio in the range of $1.0 \pm 0.1$, and equivalent dose $\left(\mathrm{D}_{\mathrm{e}}\right)<2 * \mathrm{D}_{0}$

The age calculation of the unsaturated samples was based on natural equivalent dose measurements performed on 6 to 11 aliquots per sample, while fewer aliquots per sample were measured in the case of saturated samples. In case of samples from Kender-Hill and Betlehem Quarry (Lum 2281-2285) small aliquots $(\mathrm{d}=2 \mathrm{~mm}$ ), in case of the samples from Neszmély medium aliquots $(d=5 \mathrm{~mm})$ were used for the measurements. Low overdispersion $(<20 \%)$ of the $\mathrm{D}_{\mathrm{e}}$ values with a more or less symmetric distribution is indicative of well bleached sediments at the time of deposition, and according to Olley et al. (2004) the central age model should be used to calculate their burial doses. Dose rate calculation based on high-resolution gamma spectrometry (CANBERRA-PACKARD) measurements using the conversion factors of Adamiec and Aitken (1998). Cosmic dose rates were calculated according to Prescott and Stephan (1982) and Prescott and Hutton (1994). $12.5 \pm 0.5 \%$ internal $\mathrm{K}$ content was considered for feldspar (Huntley and Baril, 1997). Based on the measurements of in-situ and saturated water content of the dated sediments, the ages were calculated using $10-12.5 \pm 2 \%$ dry-weight moisture content for the Neszmély samples and $10 \pm 5 \%$ for the Betlehem Quarry and Kender Hill samples.

\subsection{Paleontology}

Among the numerous fossil-bearing locations of the Gerecse Hills (Jánossy, 1986; Krolopp, 1990, 1995; 2014; Pazonyi, 2006; Gasparik and Kele, 2010; Pazonyi et al., 2014), the present study focuses only on remains directly unearthed from terrace material (Betlehem Quarry, Csúcsos Hill, Kender Hill) or from travertine (Kőpite Hill, Les Hill, Süttő, Vértesszőlős), or from interbedded sediments and fissure infillings in freshwater limestone (Roman Quarry, Süttő, Tata). Fossil sites and faunas not connected to geomorphic levels (caves, paleosols and loess sequences), lie beyond the scope of this study.

Previously published faunal lists of the sites were nomenclaturally and taxonomically revised based on material stored in the Vertebrate Paleontological Collections of the Hungarian Natural History Museum (HNHM) and the MBFSZ. In addition, thin sections were made from the enamel of mammoth molars from Csúcsos Hill and Les Hill, following the method developed by Ferretti $(2003,2008)$, Vasile et al. (2012), and Virág (2013). The malacological record was also revised on the basis of stratigraphic correlations provided by Krolopp $(1995,2014)$, and finally, numerical age boundaries were revised based on Lisiecki and Raymo (2005); Gibbard and Van Kolfschoten (2005), Maul and Markova (2007) and Cohen and Gibbard (2016).

\section{Sample sites and dating results}

Several dating approaches were applied for the age determination at each sample location. In order to avoid abundant repetitions, in the following sections site descriptions appear together with dating results.

\subsection{Terrace fQ9, Köpite Hill}

A Pliocene to Early Pleistocene age had previously been assigned to the Köpite Hill (fQ9, $286 \mathrm{~m}$ a.s.l. Figs. 1 and 2), one of the highest terraces of the Danube valley in the study area (Pécsi, 1959; Scheuer and Schweitzer, 1988). Gravelly and sandy sediments of $\sim 21 \mathrm{~m}$ thickness overlie Upper Miocene deltaic-littoral sediments at $\sim 265 \mathrm{~m}$ a.s.1. and were subsequently covered by travertine (Csillag et al., 2018) (Fig. 4). Sediments above and below $12 \mathrm{~m}$ depth might belong to two subsequent sedimentation phases (Fig. 4). The U/Th age of the travertine lies beyond the 600 ka limit of the method (Kele, 2009), and an imprint of an Anancus arvernensis lower third molar (inventory code: HNHM V.72.4) in the travertine suggests an age of at least 2 Ma (Jánossy, 1986; Gasparik, 2001).

The sampling at the Köpite Hill was performed along a drilling carried out at the base of an abandoned travertine quarry located at the top of the hill (286 a.s.l.). Currently the elevation of the hilltop (top of the travertine at the rim of the quarry) is $292 \mathrm{~m}$ a.s.l. According to the Third Military Survey of Hungary (1869-1887), this altitude was $294 \mathrm{~m}$ before quarrying. Therefore, at least $8 \mathrm{~m}$ of travertine has been recently removed from the terrace surface. This missing cover thickness was taken into account when performing CRN burial duration modelling.

One sample was taken every $1 \mathrm{~m}$ along the depth interval of 5-21 m. Of these, seven samples were selected for ${ }^{26} \mathrm{Al} /{ }^{10} \mathrm{Be}$ burial duration determination (Dszt-02 to -15; Fig. 4). However, as it was performed using a spiral head, the drilling did not allow recovery of undisturbed sediment samples, which generates an uncertainty of $\sim 50 \mathrm{~cm}$ in sample depths (Tables 1 and 2).

The $0.25-1 \mathrm{~mm}$ fraction of the selected samples was used for CRN analysis. The evolution of both the ${ }^{10} \mathrm{Be}$ and ${ }^{26} \mathrm{Al}$ concentrations as a function of depth modelled using the reduced $\chi^{2}$ test (Ward and Wilson, 1978) indicated the presence of 2 outlier samples (Dszt-02, -14), which were accordingly omitted from the burial duration modelling and from the discussion (Figs. 4 and 5).

The dataset under consideration enabled the modelling of the terrace age in several different ways. These are presented here from the simplest (1) to the more complex (4). For each model, pre-burial CRN production rates were assessed using an estimate of the average elevation $(600 \mathrm{~m})$ and latitude $\left(\mathrm{N}^{\circ} 8^{\circ}\right)$ of the upstream Danube catchment and a density of $2.6 \mathrm{~g} / \mathrm{cm}^{3}$, as these were more relevant than the elevation, latitude and density at the sample site. The four models were the following:

(1) The "simple bracketing model": minimum-maximum burial durations (Suppl. Fig. 1A);

(2) The "burial depth profile (BDP) model": assuming similar preand post-depositional histories of the samples using linearized data (Suppl. Fig. 1B);

(3) The "BDP model with hiatus": as in (2), but accounting for a hiatus between the terrace abandonment and the travertine precipitation (Suppl. Fig. 1C);

(4) The "BDP model with travertine aggradation": as in (2), but including a period of travertine aggradation after the terrace abandonment (Suppl. Fig. 1D).

4.1.1

(1) The "simple bracketing model"

(1a) The use of the model without post-burial production and assuming infinite burial depth yields minimum burial duration estimates between $1.87 \pm 0.23 \mathrm{Ma}$ and $2.42 \pm 0.36 \mathrm{Ma}$. This corresponds to the minimum duration necessary to reach the measured ${ }^{26} \mathrm{Al} /{ }^{10} \mathrm{Be}$ ratios from the lower curve (steady denudation) in the exposure-burial diagram, plotting the ${ }^{26} \mathrm{Al} /{ }^{10} \mathrm{Be}$ ratios as a 


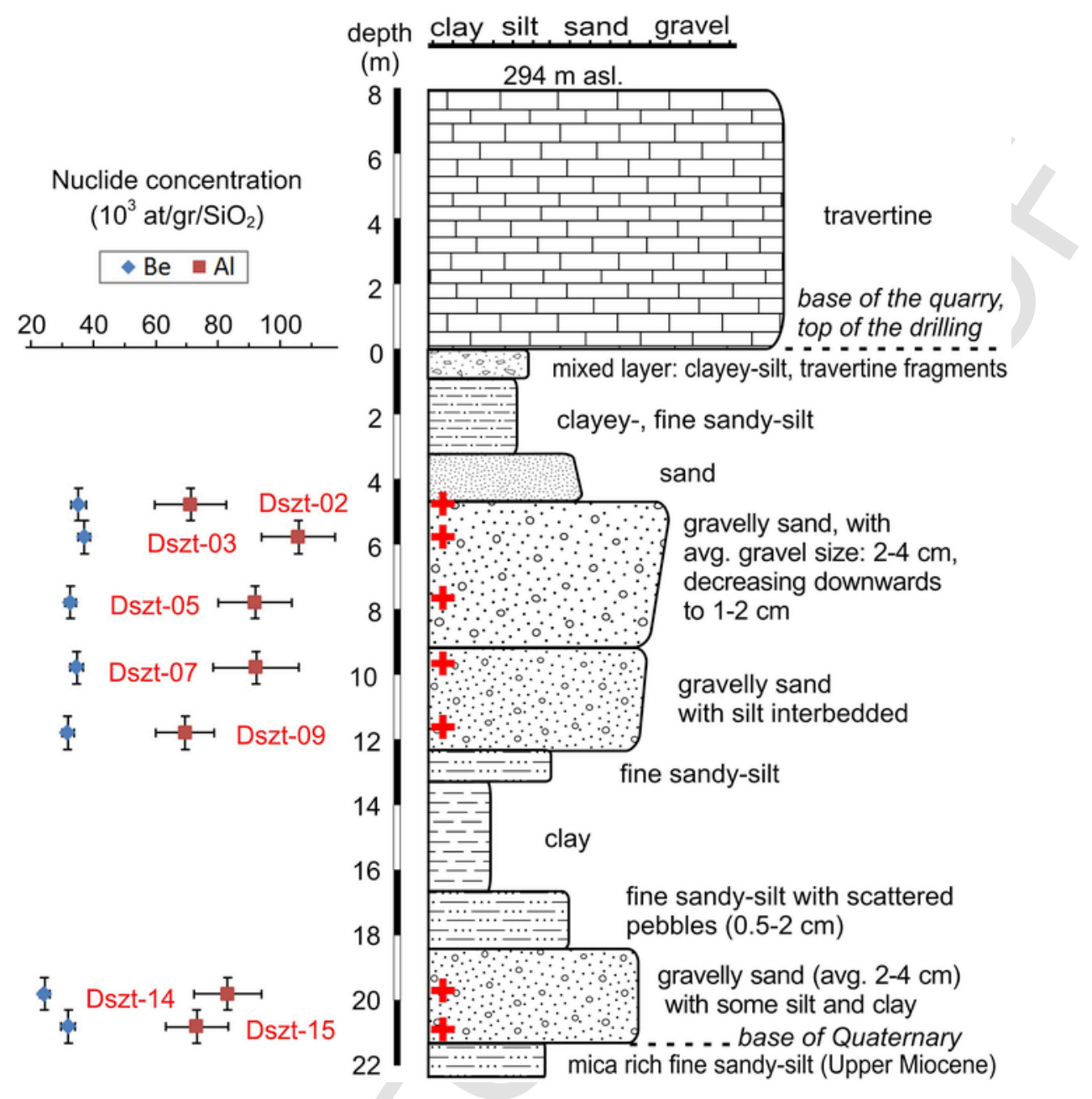

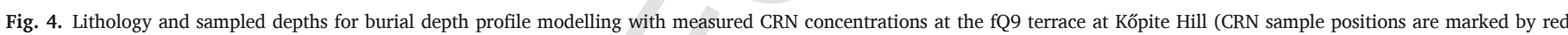

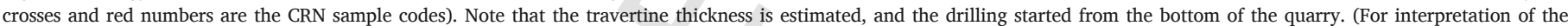
references to colour in this figure legend, the reader is referred to the Web version of this article.) function of their associated ${ }^{10} \mathrm{Be}$ concentrations (Granger, 2006, Fig. 5). The Kernel Density Estimate (KDE; Vermeesch, 2012) of the minimum burial ages and maximum denudation rates of the samples yields to the KDE minimum burial duration of $2.03 \pm 0.13 \mathrm{Ma}$ and KDE pre-burial denudation rate of $52 \pm 3 \mathrm{~m} / \mathrm{Ma}$, respectively (Suppl. Fig. 2A and B; Table 1, Suppl. Table 1).

(1b) Assuming steady denudation and post-burial CRN production, the maximum figure for the burial duration of the samples ranges from $2.35 \pm 0.37 \mathrm{Ma}$ to $3.85 \pm 0.63$ $\mathrm{Ma}$, with the KDE burial duration of $2.91 \pm 0.19 \mathrm{Ma}$. The KDE pre- and post-burial denudation rates are $66 \pm 4 \mathrm{~m}$ / Ma and $9 \pm 1 \mathrm{~m} / \mathrm{Ma}$, respectively (Suppl. Fig. 2C-E; Table 1, Suppl. Table 1). An initial travertine thickness of $33 \pm 2 \mathrm{~m}$ was calculated for this scenario (the sum of the travertine thickness removed recently by quarrying $(8 \mathrm{~m})$ and the thickness eroded since terrace abandonment (burial duration $\times$ post-burial denudation rate, $25 \pm 2 \mathrm{~m})$ ).

4.1.2

(2) The "burial depth profile (BDP) model"

(2a) The samples are treated as a buried depth profile consisting of samples that share the same pre- and post-burial histories (see details in Supplement 2.1). This model yielded a burial duration of $2.61 \pm 0.39 \mathrm{Ma}$ and a post- burial denudation rate of $16.4 \pm 2.4 \mathrm{~m} / \mathrm{Ma}$ (Table 3 ). In this scenario, the total thickness of travertine eroded/ dissolved from above the terrace is $43 \pm 6 \mathrm{~m}$, suggesting an initial travertine thickness of $51 \pm 6 \mathrm{~m}$, which is similar to the maximum travertine thickness values previously proposed for the area (Török et al., 2017; Csillag et al., 2018). The deduced pre-burial denudation rates are $72 \pm 11 \mathrm{~m} / \mathrm{Ma}$ and $57 \pm 9 \mathrm{~m} / \mathrm{Ma}$ for the upper and lower sequence, respectively.

(2b) As a subsequent step, the post-burial denudation rate was limited to $10 \mathrm{~m} / \mathrm{Ma}$, the highest denudation rate estimate from horizontal terrace surfaces in the area $\left({ }^{10} \mathrm{Be}\right.$ depth profile data; Ruszkiczay-Rüdiger et al. (2016) and this study), and a value similar to the denudation rate yielded by the KDE model taking into account post-burial CRN production. Applying this limit, the calculated burial duration is $2.93 \pm 0.43 \mathrm{Ma}$, in agreement with the KDE maximum age of the terrace. The thickness of eroded travertine is $29 \pm 4 \mathrm{~m}$, giving an initial travertine thickness of $37 \pm 4 \mathrm{~m}$, in agreement with the average travertine thickness over the area. Considering the associated uncertainties, the pre-burial denudation rates are similar to those previously deduced from the model (2a), of unconstrained post-burial denudation rate (Table 3). 
Table 2

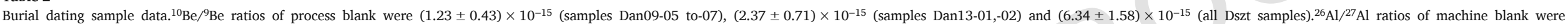

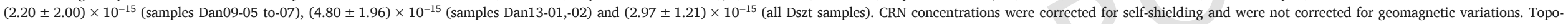
graphic shielding factor is 1 for all sites.

\begin{tabular}{|c|c|c|c|c|c|c|c|c|c|c|c|c|c|c|c|c|c|c|c|}
\hline \multirow[b]{2}{*}{ Sample } & \multicolumn{2}{|c|}{ Depth $(\mathrm{cm})$} & \multirow[t]{2}{*}{$\begin{array}{l}\text { Thickness } \\
(\mathrm{cm})\end{array}$} & \multirow[t]{2}{*}{$\begin{array}{l}\text { Mass of } \\
\text { quartz } \\
\text { dissolved (g) }\end{array}$} & \multicolumn{2}{|c|}{$\begin{array}{l}{\left[{ }^{10} \mathrm{Be}\right] \text { concentration }} \\
\text { (atoms } / \mathrm{g} \text { ) }\end{array}$} & \multicolumn{2}{|c|}{$\begin{array}{l}{\left[{ }^{26} \mathrm{Al}\right] \text { concentration }} \\
(\text { atoms/g) }\end{array}$} & $\begin{array}{l}{ }^{26} \mathrm{Al} /{ }^{10} \mathrm{Be} \\
\text { Ratio }\end{array}$ & \multicolumn{4}{|c|}{$\begin{array}{l}\text { Model (1a) with no post-burial } \\
\text { production }\end{array}$} & \multicolumn{6}{|c|}{ Model (1b) with post-burial production } \\
\hline & & & & & & & & & & & & $\begin{array}{l}\text { Pre-bur } \\
\text { denudat } \\
\text { Ma) }\end{array}$ & $\mathrm{n}$ rate $(\mathrm{m} /$ & $\begin{array}{l}\text { Max bu } \\
\text { (ka) }\end{array}$ & l age & $\begin{array}{l}\text { Pre-bu } \\
\text { denuda } \\
\text { Ma) }\end{array}$ & rate (m/ & $\begin{array}{l}\text { Post-b } \\
\text { denud } \\
\text { (m/Ma }\end{array}$ & rate \\
\hline Dszt-02 & 475 & \pm 25 & 10 & 40.8096 & 34928 & \pm 2389 & 71079 & \pm 11413 & 2.04 & 2575 & $\pm 454^{\mathrm{a}}$ & 39.2 & $\pm 6.9^{\mathrm{a}}$ & 4819 & $\pm 850^{\mathrm{a}}$ & 20.7 & $\pm 3.6^{\mathrm{a}}$ & 24.0 & $\pm 4.2^{\mathrm{a}}$ \\
\hline Dszt-03 & 575 & \pm 25 & 10 & 39.0662 & 36946 & \pm 1942 & 105771 & \pm 11748 & 2.86 & 1870 & \pm 235 & 53.1 & \pm 6.7 & 2823 & \pm 354 & 63.8 & \pm 8.0 & 14.6 & \pm 1.8 \\
\hline Dszt-05 & 775 & \pm 25 & 10 & 40.0289 & 32384 & \pm 1700 & 91797 & \pm 11902 & 2.83 & 1893 & \pm 269 & 60.1 & \pm 8.5 & 3362 & \pm 478 & 78.7 & \pm 11.2 & 9.5 & \pm 1.3 \\
\hline Dszt-07 & 975 & \pm 25 & 10 & 38.5092 & 34428 & \pm 2161 & 92228 & \pm 13763 & 2.68 & 2008 & \pm 329 & 53.2 & \pm 8.7 & 3851 & \pm 631 & 67.7 & \pm 11.1 & 5.3 & \pm 0.9 \\
\hline Dszt-14 & 1975 & \pm 25 & 10 & 38.7988 & 24039 & \pm 1613 & 83003 & \pm 10724 & 3.45 & 1488 & $\pm 220^{\mathrm{a}}$ & 99.9 & $\pm 14.8^{\mathrm{a}}$ & 1344 & $\pm 199^{\mathrm{a}}$ & 138.4 & $\pm 20.5^{\mathrm{a}}$ & 33.6 & $\pm 5.0^{\mathrm{a}}$ \\
\hline Dszt-15 & 2075 & \pm 25 & 10 & 39.3390 & 31635 & \pm 2330 & 73014 & \pm 10067 & 2.31 & 2318 & \pm 367 & 49.5 & \pm 7.8 & 2351 & \pm 372 & 73.2 & \pm 11.6 & 10.3 & \pm 1.6 \\
\hline KDE & & & & & & & & & & 2031 & \pm 133 & 52.1 & \pm 3.4 & 2912 & \pm 193 & 65.7 & \pm 4.3 & 8.5 & \pm 0.6 \\
\hline Dan09-05 & 465 & \pm 10 & 10 & 39.4137 & 147508 & \pm 5677 & 264355 & \pm 33455 & 1.79 & 2754 & \pm 371 & 7.8 & \pm 1.1 & 4063 & \pm 547 & 4.6 & \pm 0.6 & 15.1 & \pm 2.0 \\
\hline Dan09-06 & 503 & \pm 10 & 10 & 44.7793 & 174938 & \pm 5770 & 418103 & \pm 25923 & 2.39 & 2165 & \pm 161 & 8.9 & \pm 0.7 & 2757 & \pm 206 & 7.6 & \pm 0.6 & 14.3 & \pm 1.1 \\
\hline Dan09-07 & 603 & \pm 10 & 10 & 44.8995 & 106368 & \pm 6302 & 183024 & \pm 24977 & 1.72 & 2864 & \pm 432 & 10.5 & \pm 1.5 & 4558 & \pm 688 & 5.3 & \pm 0.8 & 15.7 & \pm 2.4 \\
\hline KDE & & & & & & & & & & 2323 & \pm 140 & 8.8 & \pm 0.5 & 3.038 & \pm 186 & 6.0 & \pm 0.4 & 14.7 & \pm 0.9 \\
\hline Dan13-01 & 3000 & $\pm 500^{\mathrm{b}}$ & 10 & 15.6852 & 204313 & \pm 7488 & 101034 & \pm 40008 & 0.49 & 5158 & \pm 2055 & 1.3 & \pm 0.5 & & & & & & \\
\hline Dan13-02 & 2500 & $\pm 500^{\mathrm{b}}$ & 10 & 16.3245 & 74307 & \pm 3720 & 98256 & \pm 19180 & 1.31 & 3436 & \pm 747 & 11.3 & \pm 2.3 & & & & & & \\
\hline
\end{tabular}

KDE: Kernel density estimate ages and denudation rates. (See details in text and on Suppl. Figs. 2, 3).

a Values excluded from modelling as outliers.

b Sample depth was estimated. 


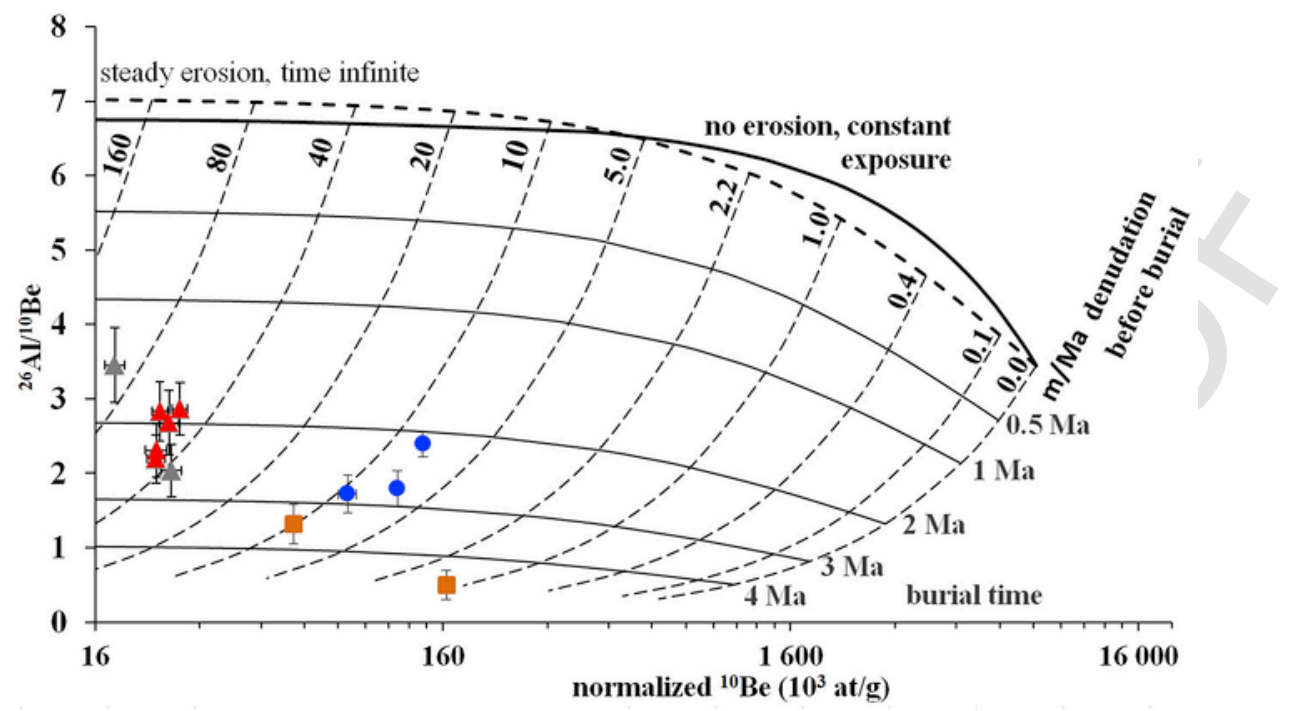

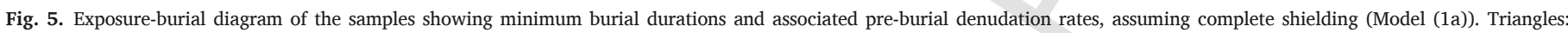
Kôpite Hill, dots: Les Hill, rectangles: Süttő. Grey triangles were omitted from modelling as outliers.

Table 3

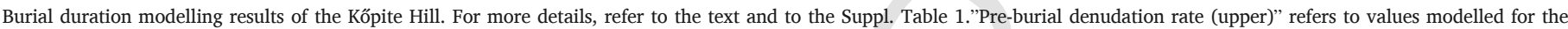
samples from the upper sedimentary unit, and "(lower)" refers to the lowermost sample (Dszt-15; Fig. 4).

\begin{tabular}{|c|c|c|c|c|c|c|c|c|c|c|c|c|}
\hline \multirow{2}{*}{$\begin{array}{l}\text { Kőpite Hill, fQ9 terrace } \\
\text { burial duration (ka) }\end{array}$} & \multicolumn{3}{|c|}{ Model (2a) } & \multicolumn{3}{|c|}{ Model (2b) } & \multicolumn{3}{|c|}{ Model (4a) } & \multicolumn{3}{|c|}{ Model (4b) } \\
\hline & 2614 & \pm & 387 & 2929 & \pm & 434 & 2588 & \pm & 431 & 2942 & \pm & 489 \\
\hline pre-burial denudation rate (upper, $\mathrm{m} / \mathrm{Ma}$ ) & 72.2 & \pm & 10.7 & 80.2 & \pm & 11.9 & 74.0 & \pm & 12.3 & 82.9 & \pm & 13.8 \\
\hline pre-burial denudation rate (lower, $\mathrm{m} / \mathrm{Ma}$ ) & 57.4 & \pm & 8.5 & 53.6 & \pm & 7.9 & 58.5 & \pm & 9.7 & 54.0 & \pm & 9.0 \\
\hline post-burial denudtion rate $(\mathrm{m} / \mathrm{Ma})$ & 16.4 & \pm & 2.4 & 10 & \pm & 0 & 17.2 & \pm & 2.9 & 10.0 & \pm & 0 \\
\hline initial travertine thickness (m) & 50.9 & \pm & 7.5 & 37.3 & \pm & 5.5 & 48.8 & \pm & 6.7 & 35.0 & \pm & 4.5 \\
\hline travertine eroded (m) & 42.9 & \pm & 6.3 & 29.3 & \pm & 4.3 & 40.1 & \pm & 6.7 & 26.9 & \pm & 4.5 \\
\hline duration of travertine aggradation (ka) & & & & & & & 250.0 & & & 250.0 & & \\
\hline travertine aggradation rate $(\mathrm{m} / \mathrm{Ma})$ & & & & & & & 195.0 & & & 140.0 & & \\
\hline
\end{tabular}

\subsection{3}

(3) The "BDP model with hiatus"

As a next step, a period of surface exposure of the terrace before its burial by the travertine was introduced in the model. Interestingly, this results in zero surface exposure duration for the terrace prior to the deposition of the travertine, indicating that there was no hiatus between terrace abandonment and travertine deposition. Consequently, the burial duration and the denudation rate estimated by this model were similar to those estimated using model (2) (Suppl. Table 1). The assumption of a scenario in which there is negligible surface exposure and denudation of the terrace before travertine precipitation is supported by the thickness of the alluvial sediments beneath the travertine unit.

\subsection{4}

(4) The "BDP model with travertine aggradation"

(4a) The CRN burial duration of the terrace was modelled according to two scenarios: the duration of travertine precipitation $\left(t_{\text {aggr }}\right.$ ) fixed at either $250 \mathrm{ka}$ or $300 \mathrm{ka}$ (for details refer to Supplement 2.1)

In the first scenario ( $t_{\text {aggr }}=250 \mathrm{ka}$ ), the required conditions are fulfilled with a travertine aggradation rate of $195 \mathrm{~m} / \mathrm{Ma}$. The resulting burial duration of the terrace is $2.59 \pm 0.43 \mathrm{Ma}$ with a post-travertine denudation rate of $17.2 \pm 2.9 \mathrm{~m} / \mathrm{Ma}$ (Table 3; Suppl. Table 1). Assuming that the $t_{\text {aggr }}$ lasted $300 \mathrm{ka}$, the best fit travertine aggradation rate is $160 \mathrm{~m} / \mathrm{Ma}$, the burial duration and the post-travertine denudation rate being similar to those resulting from the first scenario. (4b) Maximizing the post-travertine denudation rate at $10 \mathrm{~m} / \mathrm{Ma}$ (like in model (2b)) leads to a burial duration of $2.94 \pm 0.49$ Ma for both scenarios, with travertine aggradation rates of $140 \mathrm{~m} / \mathrm{Ma}$ and $115 \mathrm{~m} / \mathrm{Ma}$ in the first and second scenarios, respectively. The resulting terrace burial ages are indistinguishable from the results of model (2) (Table 3; Suppl. Table 1).

\subsection{Terrace fQ8, Roman Quarry}

To the north of the Kôpite Hill a large travertine complex is exposed by the Roman Quarry on a ridge at an elevation of $280-260 \mathrm{~m}$ a.s.l. (Figs. 1 and 2; Table 1). The gravelly sediments underlying the travertine were described only at the borders of the travertine unit. Geophysical measurements indicated that the base of the gravelly sediments lies at $\sim 245 \mathrm{~m}$ a.s.l. (Kiss et al., 2015), suggesting that the upper part of the travertine complex, where a fauna-bearing loess layer is intercalated within the travertine, covers the fQ8 horizon. To the north, another gravel horizon is exposed below the travertine at $\sim 190 \mathrm{~m}$ a.s.l. On the basis of its elevation, this sediment should belong to the fQ6 level, suggesting that the travertine has covered several terrace horizons (Figs. 1 and 2).

Based mainly on the presence of the Pitymimomys pitymyoides vole, the small mammal fauna described from the loess layer within the travertine belongs to the Late Villanyian (Jánossy, 1986). This is equivalent to the MN17 or 2.6-1.95 Ma (Fejfar et al., 1997), and provides a minimum age for the underlying fQ8 terrace. 
The reversed polarity of the Roman Quarry travertine brackets its deposition during the Matuyama chron (2.6-0.8 Ma; Lantos, 2004), which is in line with the paleontological age. The U/Th age of $>600 \mathrm{ka}$ (Kele, 2009) for the upper part of the travertine (at $264 \mathrm{~m}$ a.s.1.) does not contradict these data.

\subsection{Terrace fQ7, Les Hill}

The top of the Les Hill (232 $\mathrm{m}$ a.s.1.) is composed of travertine-cemented sandstone, the overbank fines of the Danube terrace (fQ7) (Fig. 1 , Table 1). In a somewhat lower position, in the wall of an abandoned quarry (214-220 m a.s.1.), travertine-cemented fluvial sandy-gravel is exposed, and is interpreted as the lower part of the same normal graded terrace sequence with an overall thickness of $\sim 18 \mathrm{~m}$ (Fig. 6 ). Small pebbles appear at a depth of $\sim 12 \mathrm{~m}$, at the top of the abandoned quarry wall. Conglomerate, with an average pebble size of $2-3 \mathrm{~cm}$ (up to $5 \mathrm{~cm}$ ), appears in the middle and lower sections of the outcrop (beneath a depth of $\sim 14 \mathrm{~m}$ ). The surface of the abandoned quarry presents a somewhat uncertain picture, as the recent removal of a considerable thickness of sediments from above the sampled quarry wall is possible, given that limestone quarrying in the area started as early as of the times of the Roman Empire.

Three in situ Mammuthus meridionalis teeth were described within the sandy gravel body (Halaváts, 1898; Schréter, 1953; Scheuer and Schweitzer, 1988, Fig. 6). The overall morphology of the teeth and the microstructure of their enamel place them as transitional between $\mathrm{M}$. rumanus (latest Pliocene to earliest Pleistocene) and M. meridionalis (Early Pleistocene). Based on their ancient morphology, the studied molars can be identified as early representatives of the latter taxon (Virág and Gasparik, 2012; Virág, 2013), suggesting an age of 2.4-2.0 Ma for this terrace.

The prevailing reversed magnetic polarity, with a short period of normal polarity in the upper part of the sequence places the travertine of the Les Hill in the older part of the Matuyama chron, around the Olduvai event (2.6-1.6 Ma; Lantos, 2004).

By way of contrast, freshwater limestone from a neighbouring travertine quarry on the Les Hill yields U/Th ages ranging from $408 \pm 73 \mathrm{ka}$ to $273 \pm 73 \mathrm{ka}(\mathrm{n}=3$; Kele, 2009), that is, considerably younger than the paleontological and magnetostratigraphic ages.

The sandstone at the hilltop and on the top of the outcrop and pebbles of $\mathrm{cm}$ size at 4-6m depth in the conglomerate were sampled to es-

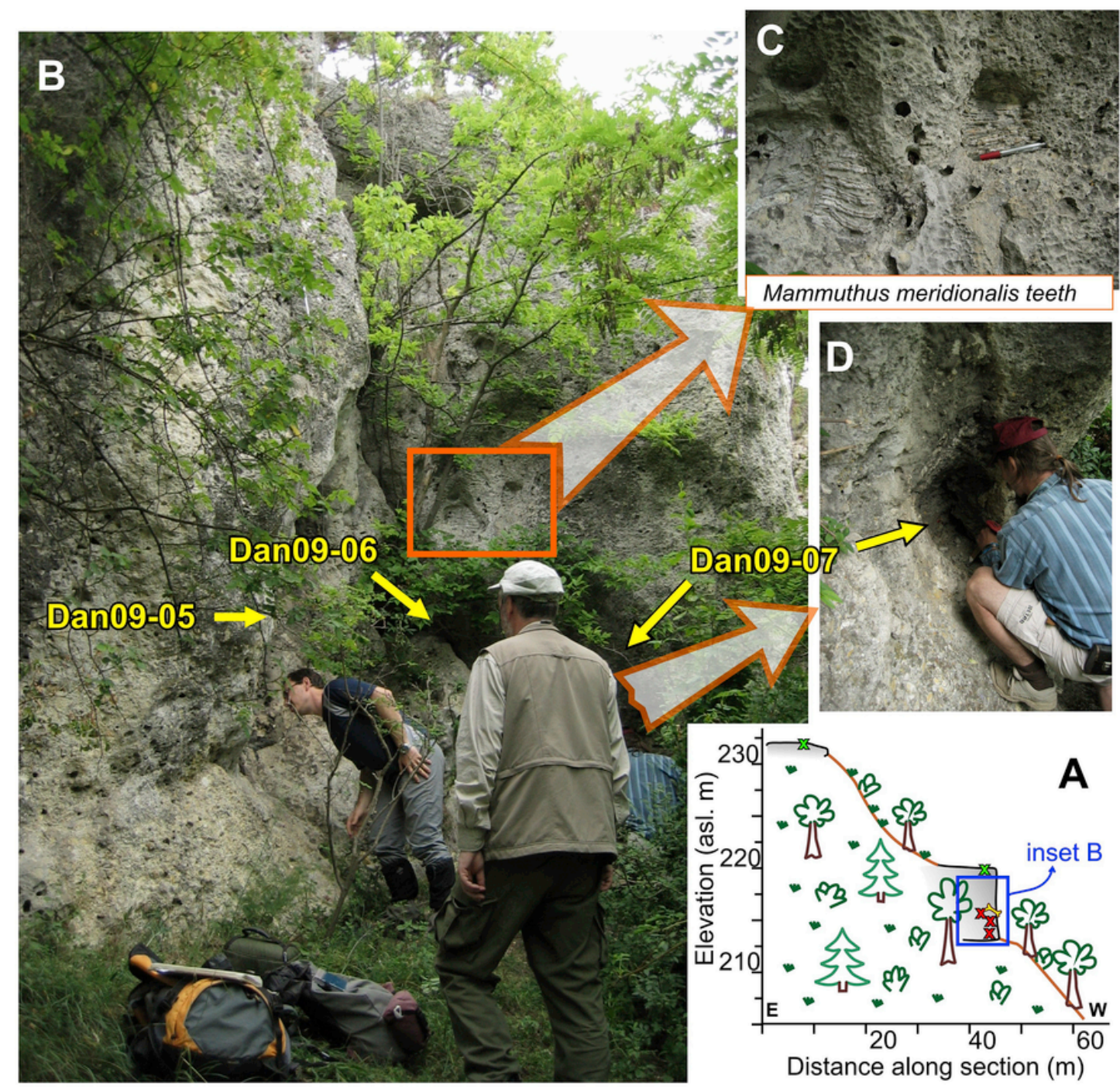

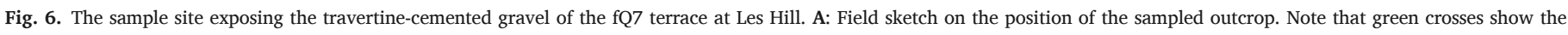

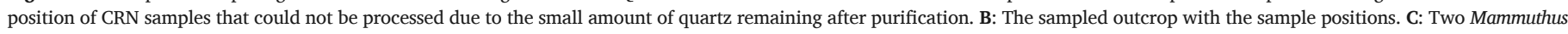

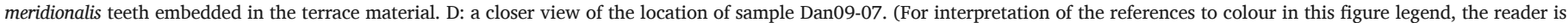
referred to the Web version of this article.) 
timate exposure and burial duration from the resulting ${ }^{26} \mathrm{Al} /{ }^{10} \mathrm{Be}$ depth profile ( $n=5$; Fig. 6 ). Unfortunately, the sand contained in the two surface samples was totally dissolved in the course of quartz separation and leaching (Dan09-03, -04; do not appear in Table 2), and only the remaining 3 deep samples from the 4.7-6.0 $\mathrm{m}$ depth range could be used for the measurement of their ${ }^{26} \mathrm{Al}$ and ${ }^{10} \mathrm{Be}$ concentrations (Dan09-05 to -07; Table 2; Fig. 6).

The burial duration of the fQ7 terrace at the Les Hill was estimated using the "simple bracketing model" (Model (1)).

(1a) Assuming complete burial and no post-burial production (i.e. the recent truncation of $>10 \mathrm{~m}$ material), a minimum burial duration of $2.17 \pm 0.16 \mathrm{Ma}$ for the youngest sample, together with an $8.9 \pm 0.7 \mathrm{~m} /$ Ma pre-burial denudation rate were obtained (Fig. 5). The KDE of the calculated minimum burial durations leads to a minimum KDE burial duration of $2.32 \pm 0.14 \mathrm{Ma}$ with a pre-burial denudation rate of $8.8 \pm 0.5 \mathrm{~m} / \mathrm{Ma}$ (Table 2, Suppl. Fig. 3A and B).

(1b) Assuming stable conditions after burial and taking post-burial production into account, a maximum KDE burial duration of $3.04 \pm 0.19 \mathrm{Ma}$ is estimated with a pre-burial denudation rate of $6.0 \pm 0.4 \mathrm{~m} / \mathrm{Ma}$ and a post-burial surface denudation rate of $14.7 \pm 0.9 \mathrm{~m} / \mathrm{Ma}$ (Table 2, Suppl. Fig. 3C-E).

\subsection{Terrace fQ7, Csúcsos Hill}

A travertine-cemented conglomerate unit was described on the Csúcsos Hill (223 m a.s.l. Figs. 1 and 2, Table 1) with an estimated thickness of $\sim 8 \mathrm{~m}$ above Upper Miocene sandy sediments (Schréter, 1953). The oncoidic structure of the travertine around the pebbles suggests that the fluvial material was deposited close to the karstwater spring. To the north, northwest from the peak, at $\sim 215 \mathrm{~m}$ a.s.l. several travertine units without siliciclastic sediments have also been described (Scheuer and Schweitzer, 1988); these most probably cover the same terrace horizon.

Four Mammuthus meridionalis teeth were mentioned from the Csúcsos Hill conglomerate by Scheuer and Schweitzer (1988). Their morphological and microstructurural study (Virág and Gasparik, 2012; Virág, 2013; HNHM V.82.49, HNHM V.82.50, HNHM V.88.11, and a lower left $\mathrm{m} 3$ without an inventory number) suggests their similarity to the teeth from the Les Hill. These are therefore also considered to be early representatives of $M$. meridionalis with a most probable age range of 2.4-2.0 Ma.

\subsection{Terrace fQ8-7 (?), Süttó}

To the south of Süttô village, one of the largest travertine deposits in Hungary is exposed in several active quarries at elevations, ranging from 278 to $215 \mathrm{~m}$ a.s.l. (Fig. 1, Table 1). The underlying gravelly sediments (gravelly-sandy clay and travertine-cemented gravel) have been described as a Danube terrace (tV, Pécsi et al., 1984). Given the significant elevation range, several terrace horizons (fQ6-7-8) may have been covered by the travertine (similarly to the Roman Quarry travertine on Fig. 2). The gravel-bearing sediments (1-10 m thick) cover the eroded surface of Upper Miocene sand.

The travertine beds follow pre-existing valleys, and travertine precipitation took place on gently sloping terrain (Török et al., 2017). The recent re-evaluation of the drill hole data in and around the travertine complex suggests that the gravel at the base of the travertine is not in its original position, but has been re-deposited from an older terrace, or from Eocene siliciclastic lithologies (Csillag et al., 2018). The travertine is fractured by several fissures filled with sediments post-dating the formation of the travertine (Pazonyi et al., 2014). Most of the fractures are the result of the gravitational sliding of the travertine above the sandy-clayey basal sediments (Török et al., 2017).

Among the numerous fossil remains (Pazonyi et al., 2014), only the occurrences providing information on the time of travertine precipitation are mentioned (Table 1).

At the highest position (Cukor Quarry; 270-260m a.s.1.), the co-occurrence of Mimomys pusillus and Mimomys pliocaenicus in cemented red clay filling a cave within the travertine suggests an age of 2.0-1.8 Ma age (second half of the MN17) (Pazonyi et al., 2014). This provides a minimum age for the travertine. A sandy gravel unit with no fauna outcropping next to the Cukor Quarry at ( $265-275 \mathrm{~m}$ a.s.l) was tentatively correlated with the fQ8 terrace (Fig. 1).

An age range of 2.0-0.8 Ma is suggested by the presence of Mimomys pusillus within the red clay layer at the somewhat lower-lying Újharaszt Quarry (250-240 m a.s.l.; Süttő 19).

At a similar elevation Anancus arvernensis, Dicerorhinus cf. jeanvireti, Cervus cf. philisi have been found in the travertine (Hegyhát Quarry, 255-240 m a.s.1.) in addition to Arvernoceros cf. ardei found in the top layer of the neighbouring Gazda Quarry (240-215m a.s.1.) (Jánossy and Krolopp, 1981). Considering the bio-stratigraphic ranges of these vertebrates, a minimum age of $\sim 2.0$ Ma can be assigned to this site.

The 1.0-0.9 Ma minimum age of the fauna (co-occurrence of $\mathrm{Mi}$ momys savini, Pliomys episcopalis, P. lenki, Microtus (Allophaiomys) pliocaenicus, Microtus (Terricola) hintoni voles) from a fissure infilling (red clay covered by sandy loess) within the upper travertine unit (Süttő 17, Hegyhát Quarry) is in agreement with an age of $>2 \mathrm{Ma}$ for the host rock.

The magnetic polarity of the travertine at Süttó is variable. Both reversed and normal polarity sections have been described in two quarries, and travertine formation around the Matuyama-Gauss boundary has been suggested (3-2.1 Ma; Lantos, 2004).

In contrast, U/Th ages ranging between 422 and 210 ka (Kele, 2009; Sierrallta et al., 2010) suggest a Middle Pleistocene age for travertine precipitation. In addition, the $\mathrm{U} / \mathrm{Th}$ ages do not exhibit a consistent trend with the stratigraphic order within the travertine unit. On the top of the eroded surface of the Süttô Travertine Complex an Upper Pleistocene loess layer, dated by OSL, was deposited (Novothny et al., 2011).

For ${ }^{26} \mathrm{Al} /{ }^{10} \mathrm{Be}$ burial duration determination two samples were collected from the gravelly sediment underlying the $20-50 \mathrm{~m}$ thick travertine complex in the Gazda Quarry, at an elevation corresponding to the fQ7 terrace (Fig. 7). Dan13-01 was collected from the gravelly clay below the travertine, and Dan13-02 originated from a travertine-cemented conglomerate block at the base of the quarry. Sample depths had to be estimated, since all or part of the travertine covering the gravel has been removed by quarrying (Table 2). Low ${ }^{26} \mathrm{Al} /{ }^{10} \mathrm{Be}$ isotopic ratios yield to $5.16 \pm 2.06 \mathrm{Ma}$ and $3.44 \pm 0.70 \mathrm{Ma}$ minimum burial duration estimates for the gravelly clay and conglomerate, respectively, assuming no post-burial CRN production. The associated pre-burial denudation rates are $1.3 \pm 0.5 \mathrm{~m} / \mathrm{Ma}$ and $11.3 \pm 2.3 \mathrm{~m} / \mathrm{Ma}$, respectively (Fig. 5, Table 2). Due to the low CRN concentrations and great thickness of the cover, the model including post-burial CRN production was not performed on these samples.

\subsection{Terrace fQ5, Betlehem Quarry}

In the abandoned gravel pit of the Betlehem Quarry, a Middle Pleistocene (?) Danube terrace ( $178 \mathrm{~m}$ a.s.l. fQ5) is exposed on the north-western slope of the Csúcsos Hill (Figs. 1 and 2, Table 1). The sandy gravel of the terrace is poorly sorted. The thickness of the Quaternary fluvial sediments is estimated to be $\sim 7 \mathrm{~m}$, because the contact could not be properly studied due to its coverage by debris (Fig. 8). Several large travertine blocks (up to $\sim 5-6 \mathrm{~m}$ size) are present within the terrace gravel. Whether they represent remnants of a former freshwater 


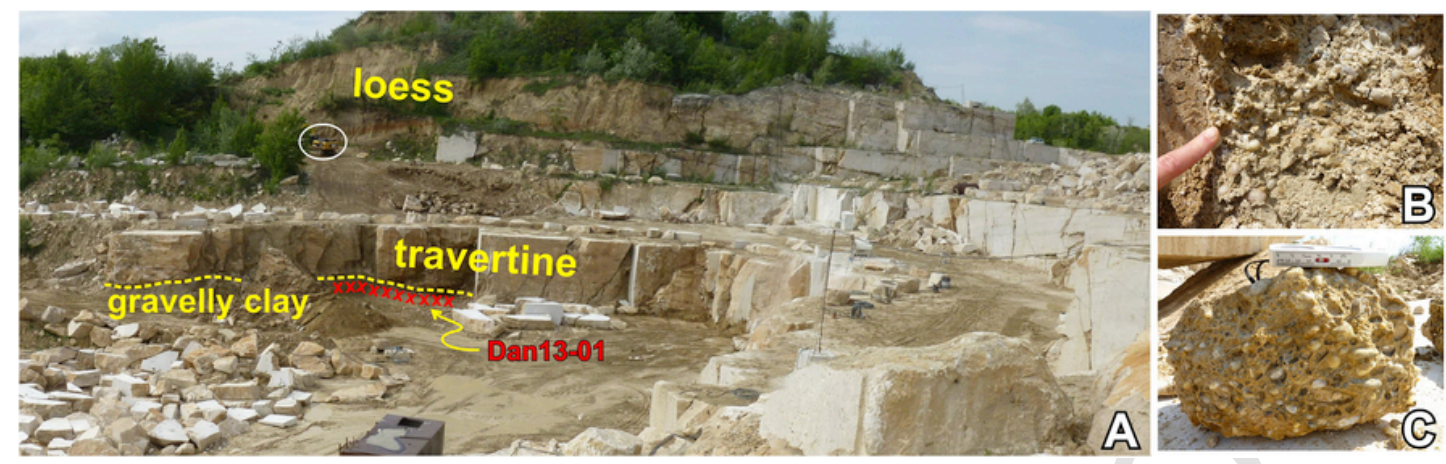

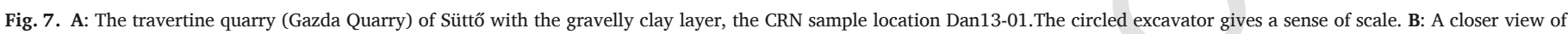
the gravelly clay at the base of the travertine. C: The travertine-cemented conglomerate of Dan13-02 sample coming from the opposite wall of the same quarry.
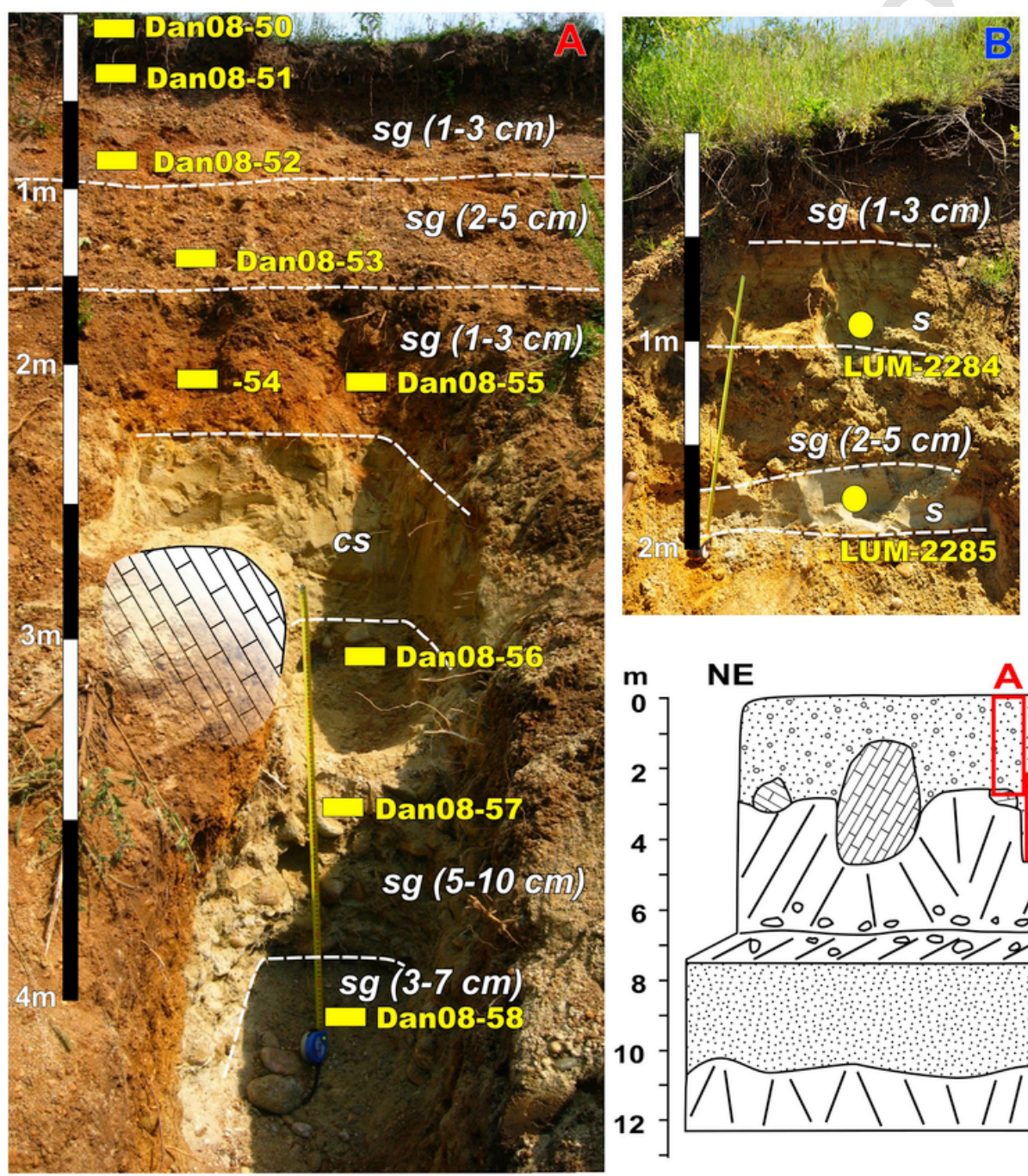

\section{Legend}

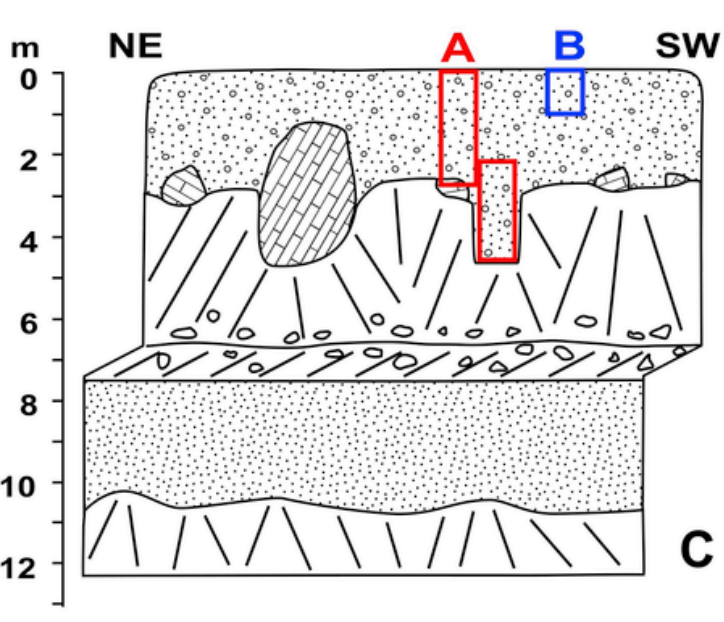

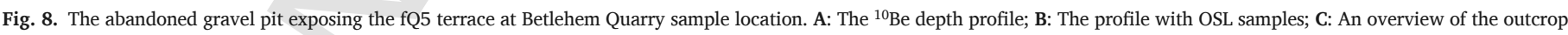

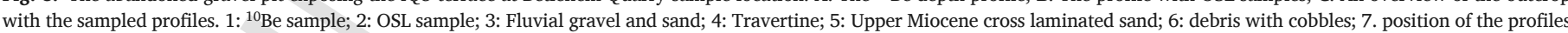
shown by the A and B insets. sg: sandy gravel (with main pebble size); cs: coarse sand.

limestone spring cone (Scheuer and Schweitzer, 1988; Viczián, 2013), or had slumped gravitationally in the terrace material from a higher travertine body (Scheuer, 1997) is open to debate. Recent geophysical measurements (Kiss et al., 2014) do not provide evidences for the presence of deeper travertine deposits, but do support the likelihood of travertine blocks "floating" in the sandy-gravelly material (Fig. 2).
The gastropod assemblage described from the fluvial sediment of the Betlehem Quarry suggests a late Early Pleistocene age for the terrace: $~ 1.1-0.78 \mathrm{Ma}$ (Gastrocopta sacraecoronae Subzone; youngest part of Viviparus boeckhi Zone (Krolopp, 1995, 2014). In addition, Viczián (2013) described a fragmented Mammuthus meridionalis molar from the upper part of the fluvial material. The biostratigraphical range of this taxon is regionally 2.4-0.8 Ma. As the specimen was lost, it was not 
possible to narrow this age range through morphological and microstructural investigations.

CRN samples were collected from the sandy gravel at the surface down to a depth of $4 \mathrm{~m}(\mathrm{n}=9$; Dan08-50 to -58 ; Table 4$)$. The profile had to be shifted laterally due to a travertine body being concealed by the terrace material (Fig. 8). The bulk samples were sieved and small pebbles $(1-5 \mathrm{~cm}$ size) were processed for CRN analysis as amalgamated pebble samples. Ruszkiczay-Rüdiger et al. (2016) conformed that the depth profiles of amalgamated pebble samples are as suitable for the exposure age determination of Danube terraces in the Pannonian Basin as profiles of sand samples.

The integration time calculated for the Betlehem Quarry was only $110 \mathrm{ka}$ at the surface, but reached $\sim 830 \mathrm{ka}$ at a depth of $4 \mathrm{~m}$ (Table 5). For depth profile modelling, the ${ }^{10} \mathrm{Be}$ concentrations of the Dan08-54 and -55 samples taken at the same subsurface depth were averaged to run the Hidy et al. (2010) Monte Carlo simulator (Fig. 9A). Based on the classic assumption that this terrace is older than the Mindel glaciation but younger than the earliest Pleistocene (Pécsi, 1959), the model age limits were set at $540 \mathrm{ka}$ and $1.8 \mathrm{Ma}$. The model denudation rate limits were set based on geological and sedimentological observations (Csillag et al., 2018). The input parameters for the depth profile simulator are presented by Table 5 .

Using Bayesian statistics, the most probable exposure age, denudation rate and inheritance values are similar to the mean and median values determined by the Hidy et al. (2010) depth profile simulator (Table 6). Therefore, the Bayesian approach gives a most probable exposure age of $1.12^{+0.23} /{ }_{-0.40}$ Ma in association with a denudation rate of $11^{+1 /-1} \mathrm{~m} / \mathrm{Ma}$ ( $1 \sigma$ uncertainty). This age could be regarded as the most probable CRN age of abandonment for terrace fQ5 in Betlehem Quarry (Table 6). On the other hand, the best fitting of the evolution of the ${ }^{10} \mathrm{Be}$ and ${ }^{26} \mathrm{Al}$ concentrations as a function of depth $\left(\min \chi^{2}\right)$ indicates older ages ("Age vs denudation rate" and "Age probability density function" plots on Fig. 9A), while the calculated denudation rates remain fairly constant, at around $10 \mathrm{~m} / \mathrm{Ma}$ ("Denudation probability density function" plot on Fig. 9A). Unchanging denudation rates for large differences in exposure ages are characteristic of depth profiles at steady state. Besides, the $\sim 1.1 \mathrm{Ma}$ age model is larger than the datable time range defined by the integration time calculated from the profile (Table 4). Accordingly, we suggest the use of more conservative $>713$ ka Bayesian $1 \sigma$ lower age as the minimum CRN age of terrace abandonment at this location.

Luminescence sampling of sand lenses was performed at depths of 1.0 and $1.7 \mathrm{~m}$ (Table 7, Fig. 8). A dose-recovery test resulted in an average dose-recovery ratio of $1.12 \pm 0.08$, indicating slightly higher measured dose values than the given laboratory doses. However, with regard to the pIRIR signal of K-feldspar, a poor dose recovery ratio does not necessarily mean an inaccurate measurement of $\mathrm{D}_{\mathrm{e}}$ (Buylaert et al., 2012). The average $g$-value $\left(g_{2 \text { days }}\right)$ is $0.8 \pm 0.6 \%$ /decade. Low fading rates are probably a laboratory artefact (Thiel et al., 2011), so fading correction was not applied to these samples. The pIRIR ${ }_{290}$ signal of both samples (LUM-2284, -2285) approached saturation (976 Gy and $877 \mathrm{~Gy}$, respectively). Considering the dose rates of the samples a pIRIR 290 minimum age of $>347 \mathrm{ka}$ and $>365$ ka was calculated for the samples, respectively, and these were in agreement with the CRN and palaeontological ages of this site.

\subsection{Terrace fQ4 - pediment pQ4, Vértesszólös}

The terrace sediments of the Által-ér creek were mostly eroded from the fQ4 terrace at Vértesszôlós ( $176 \mathrm{~m}$ a.s.l. at the base of the terrace covering travertine). The terrace is covered by tetarata-type travertine of up to $\sim 10 \mathrm{~m}$ in thickness (Hennig et al., 1983). According to the revised drill-hole data, only a small occurrence of terrace sediments (up to $\sim 6 \mathrm{~m}$ thickness described from one drillhole) has been preserved between the travertine and the Oligocene sedimentary rocks (Csillag et al., 1018). Further uphill, the travertine is deposited on to the pQ4 pediment surface, which developed coevally with the fQ4 terrace. The missing terrace sediments suggest the presence of a denudation event before travertine precipitation at this location. Due to the absence of available siliciclastic material, this terrace could not be targeted by the CRN or IRSL methods.

Early interest in the numerical dating of the site stems from its archaeological importance and reputation: an early human occipital bone and some teeth with numerous stone tools belonging to the Paleolithic pebble industry were found in the upper third of the terrace-covering travertine (Kretzoi and Dobosi, 1990 and references therein). The occipital bone of Vértesszőlös belongs to the Homo heidelbergensis taxon (Bradák et al., 2013), which is of similar age or slightly older than the human remains found at the Sima de los Huesos, Atapuerca, Spain (Arsuaga et al., 2014), which represent a human taxon transient from Homo heidelbergensis towards the Homo neanderthalensis and were dated to be older than $\sim 430 \mathrm{ka}$.

The travertine quarries with the archaeological site are at an elevation of $\sim 180 \mathrm{~m}$ a.s.l. (Fig. 1, Table 1 ). U/Th dating of the travertine by Pécsi and Osmond (1973), Hennig et al. (1983), Cherdintsev and Kazachevksi (1990), Osmond (1990), and by Schwarcz and Latham (1990) gives figures ranging from $128 \pm 19 \mathrm{ka}$ to $>350 \mathrm{ka}$ (the limit of the U/Th method). ESR based dating also ranges from $127 \pm 13 \mathrm{ka}$

Table 4

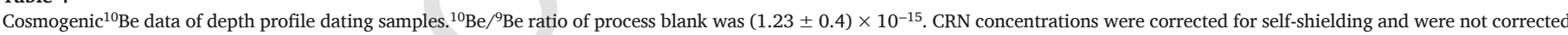

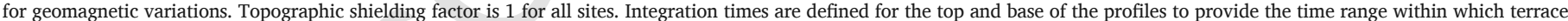
age can be determined using the depth profile data.

\begin{tabular}{|c|c|c|c|c|c|c|c|c|c|}
\hline \multirow{2}{*}{$\begin{array}{l}\text { Sample } \\
\text { Dan08-50 }\end{array}$} & \multicolumn{2}{|c|}{ Depth $(\mathrm{cm})$} & \multirow{2}{*}{$\begin{array}{l}\text { Thick-ness } \\
(\mathrm{cm})\end{array}$} & \multirow{2}{*}{$\begin{array}{l}\text { Mass of quartz dissolved } \\
(\mathrm{g})\end{array}$} & \multicolumn{2}{|c|}{$\begin{array}{l}{\left[{ }^{10} \mathrm{Be}\right] \text { concentration (atoms/ }} \\
\text { g) }\end{array}$} & \multicolumn{2}{|c|}{$\begin{array}{l}\text { Max. denudation rate (m/ } \\
\text { Ma) }\end{array}$} & \multirow{2}{*}{$\begin{array}{l}\text { Site specific integration time } \\
\text { (ka) } \\
\sim 110\end{array}$} \\
\hline & 0 & \pm 5 & & & 357727 & \pm 15791 & 10.9 & \pm 0.5 & \\
\hline Dan08-51 & 31 & \pm 5 & 8 & 41.0681 & 293789 & \pm 12323 & 9.1 & \pm 0.4 & \\
\hline Dan08-52 & 81 & \pm 5 & 8 & 41.2824 & 153521 & \pm 4491 & 10.9 & \pm 0.3 & \\
\hline Dan08-53 & 141 & \pm 5 & 8 & 39.8232 & 91636 & \pm 2870 & 11.3 & \pm 0.4 & \\
\hline Dan08-54 & 211 & \pm 5 & 8 & 39.1286 & 88195 & \pm 2664 & 6.3 & \pm 0.2 & \\
\hline Dan08-55 & 211 & \pm 5 & 8 & 40.3495 & 53998 & \pm 2196 & 13.3 & \pm 0.5 & \\
\hline Dan08-56 & 301 & \pm 5 & 8 & 42.2498 & 56354 & \pm 2188 & 7.4 & \pm 0.3 & \\
\hline Dan08-57 & 345 & \pm 5 & 8 & 42.4714 & 49355 & \pm 2089 & 7.9 & \pm 0.3 & \\
\hline Dan08-58 & 401 & \pm 5 & 8 & 41.4192 & 48490 & \pm 1634 & 6.7 & \pm 0.2 & $\sim 830$ \\
\hline Dan09-09 & 138 & \pm 5 & 5 & 41.6812 & 71150 & \pm 4757 & 16.4 & \pm 1.1 & $\sim 80$ \\
\hline Dan09-10 & 258 & \pm 5 & 5 & 40.7654 & 42323 & \pm 2917 & 15.0 & \pm 1.0 & \\
\hline Dan09-11 & 352 & \pm 5 & 5 & 40.9727 & 43272 & \pm 2322 & 10.1 & \pm 0.5 & \\
\hline Dan09-12 & 428 & \pm 5 & 5 & 43.0949 & 47963 & \pm 2972 & 6.6 & \pm 0.4 & \\
\hline Dan09-13 & 508 & \pm 5 & 5 & 41.1312 & 37480 & \pm 2317 & 9.6 & \pm 0.6 & $\sim 880$ \\
\hline
\end{tabular}


Table 5

Monte Carlo simulation parameters used for the depth profile simulator of Hidy et al. (2010). 100000 solutions were requested for each simulation. Density was a variable between 1.8 and $2.2 \mathrm{~g} / \mathrm{cm}^{3}$.

\begin{tabular}{lll}
\hline Thresholds & Betlehem & Kender \\
\hline & Quarry & Hill \\
\hline$\chi^{2}$ cutoff & 3.5 & 3 \\
min erosion rate $(\mathrm{cm} / \mathrm{ka})$ & 0.5 & 0.5 \\
max erosion rate $(\mathrm{cm} / \mathrm{ka})$ & 1.5 & 4 \\
total erosion min. $(\mathrm{cm})$ & 600 & 300 \\
total erosion max. $(\mathrm{cm})$ & 1600 & 1600 \\
min. age $(\mathrm{ka})$ & 540 & 130 \\
max. age $(\mathrm{ka})$ & 1800 & 1000 \\
site specific spallogenic & 4.7501 & 4.7082 \\
production rate $(\mathrm{at} / \mathrm{g} / \mathrm{a})$ & & \\
\hline
\end{tabular}

to $386 \pm 39 \mathrm{ka}$ (Hennig et al., 1983). The normal magnetic polarity of the travertine implies a maximum age of $<0.78 \mathrm{Ma}$ for travertine precipitation (Latham and Schwarcz, 1990; Lantos, 2004).

Most of the fauna was recovered at the Vértesszőloos II site located approximately $120 \mathrm{~m}$ north of the well-known Paleolithic site (Vértesszőlős I) from a strongly cemented grey calcaerous aleurolite and from the overlying sandy loess layers. Kordos (1994) associated the Vértesszőlős II. fauna with the Holsteinian interglacial (MIS11, 400 ka).

On the basis of Arvicola mosbachensis, Stephanorhinus hundsheimensis and Cervus elaphus priscus, Van der Made $(2010,2015)$ correlated the age of the site rather with the latest interglacial of the 'Cromerian complex' or to the Holsteinian interglacial (MIS13 or 11, 500-400 ka). Considering the time ranges presented in Van der Made et al. (2003) and Van der Made (2011), the presence of Bison schoetensacki and Ursus deningeri also confirms this age model. A few species mentioned by Jánossy (1990), namely Panthera gombaszogensis and Pachycrocuta brevirostris, suggest an older age however, this issue cannot be resolved without a more detailed revision of the available material. Accordingly, the most likely age of $450 \pm 50 \mathrm{ka}$ of the terrace-covering travertine provides a minimum age for the fQ4 and connected pQ4 levels at the Által-ér Creek. This age is in agreement with the numerically dated human remains of Atapuerca (Arsuaga et al., 2014) site. The published fauna of the Vértesszôlős I. Palaeolithic site is relatively poor, based on its small mammal remains it appears to be coeval or slightly younger than the Vértesszőlős II site (Kordos, 1994).

\subsection{Pediment $p Q 4-3 b$, Kender Hill}

The abandoned sandpit of the Kender Hill (172m a.s.l.; Fig. 1, Table 1) exposes fluvial sand at a depth of $\sim 6 \mathrm{~m}$, intercalated with $5-10 \mathrm{~cm}$ thick sub-horizontal gravelly sand layers in the $80-120 \mathrm{~cm}$ interval. An average pebble size of $2-3 \mathrm{~cm}$ in the upper part of the outcrop decreases to $0.5 \mathrm{~cm}$ in the lower part. Redeposited Late Miocene shells (Congeria ungulacaprae casts) are frequent. This sediment was most probably deposited by ephemeral creeks crossing the NW sloping pediment surface of the western Gerecse Hills. The truncated surface of the fluvial material is covered by a $90-130 \mathrm{~cm}$ layer of eolian sand (well sorted, with steep, dune-like bedding). Geomorphological mapping suggests that the fluvial sediments exposed in the Kender Hill quarry belong to the higher part of the pQ4-3b pediment of the western Gerecse Hills and may be correlated either to the terrace fQ4 or fQ3b of the Danube - Által-ér terrace system.

The paleontological age deduced from the gastropod fauna described in a neighbouring sand pit indicates a Middle Pleistocene age for this pediment surface and the related fQ4-3b terraces (Helicigona vertesi Zone; (Krolopp, 1995, 2014; MIS15-MIS6; 650-130 ka). This is in agreement with the age of the horizon in the traditional terrace system (Pécsi, 1959).

CRN samples were collected in the gravelly sand layers of the fluvial material for ${ }^{10} \mathrm{Be}$ concentration measurements along a depth profile extending from 140 to $510 \mathrm{~cm}$ depth $(\mathrm{n}=5$; Dan09-09 to -13 ) (Tables 1 and 4; Fig. 10A). The sand was sieved and amalgamated pebble samples were processed. No sample from the eolian sand layer was analysed for CRN.

The integration time at the surface of the Kender Hill site is $\sim 80 \mathrm{ka}$ and $\sim 880$ ka at a depth of $5 \mathrm{~m}$.

The Monte Carlo depth profile simulator (Hidy et al., 2010) was not able to provide a unique solution to the question of the exposure duration - denudation rate - inheritance triplet when the Dan09-12 sample was considered. This outlier was therefore discarded from the depth profile modelling. The threshold age values applied in the simulation (1 Ma - $130 \mathrm{ka}$ ) were based on the supposed $\sim$ Middle Pleistocene age of the terrace, and the denudation rate thresholds were settled using geological and sedimentological observations (Table 5).

The Bayesian most probable exposure age, denudation rate and inheritance values are in agreement within a tolerable margin of error with the mean and median values determined by the Hidy et al. (2010) depth profile simulator (Table 6, Fig. 9B). They are, in addition, lower than the integration time calculated for the deepest sample at this site. The considerable scatter of the best fitting model solutions of exposure age with well-defined denudation rates ("Age vs denudation rate" and "Age probability density function" plots on Fig. 9B) may also indicate that the upper part of the profile has reached secular equilibrium, while in the lower part the CRN accumulation is still faster than decay. Therefore, the Bayesian most probable exposure age of $404^{+248} /{ }_{-168}$ ka ( $1 \sigma$ uncertainty) was assumed as the most probable CRN age for the abandonment of this pediment surface associated with a denudation rate of $20^{+8} /{ }_{-3} \mathrm{~m} / \mathrm{Ma}$. The large error bars result from the uncertain upper part of the profile (" ${ }^{10} \mathrm{Be}$ concentration vs depth" plot on Fig. 9B).

Two samples (LUM-2281, -2282) were taken from the fluvial sand and one from the eolian cover (LUM-2283) for pIRIR $_{290}$ age determination (Tables 1 and 7, Fig. 10A). A dose-recovery test was carried out on the samples after a $3 \mathrm{~h}$ bleaching in a Hönhle solar simulator to test the reliability of the applied protocol. The average dose-recovery ratio was $1.08 \pm 0.06$. The measured residual dose was $13.4 \pm 0.5 \mathrm{~Gy}$ (LUM-2283). This residual dose was subtracted from the equivalent dose $\left(D_{\mathrm{e}}\right)$ of the corresponding samples.

The fading test resulted in an average g-value of $1.45 \pm 0.6 \%$ / decade, so fading correction was not applied. One of the fluvial samples (LUM-2281; Fig. 11A) was already saturated, therefore only a minimum age of deposition was calculated. A saturation dose of $779 \mathrm{~Gy}$ was determined for this sample, corresponding to the minimum age of $>327$ ka. The pIRIR 290 signal of the other fluvial sample (LUM-2282) also approached its saturation level $(83 \%)$, but a pIRIR 290 age could still be determined with confidence (Fig. 11B). Due to the prolonged measurement time $n=9$ aliquots were measured from this sample. The distribution of the $\mathrm{D}_{\mathrm{e}}$-s was almost symmetric (Fig. 11C) and the overdispersion of the De-s was only $6.4 \%$, therefore the mean and central age model (CAM) of Galbraith et al. (1999) were calculated. Both resulted in almost identical De-s, finally the CAM $\mathrm{D}_{\mathrm{e}}$ was considered for the interpretation, although CAM is usually used in larger data set. The low dose rate of this sample allowed us to calculate a pIRIR 290 age of $471 \pm 41 \mathrm{ka}$ (Table 7), in line with the CRN and paleontological ages.

For the sample collected from the eolian cover (LUM-2283; Fig. 11D), complete bleaching was assumed and the mean of the $D_{e}-\mathrm{s}$ of the measured aliquots $(n=11)$ was taken to calculate the $\operatorname{pIRIR}_{290}$ age of the sample. The pIRIR 290 age of this sample is $13.4 \pm 1.0 \mathrm{ka}$, suggesting that the eolian deposition occurred during the latest Pleistocene. 


\section{A Betlehem Quarry}
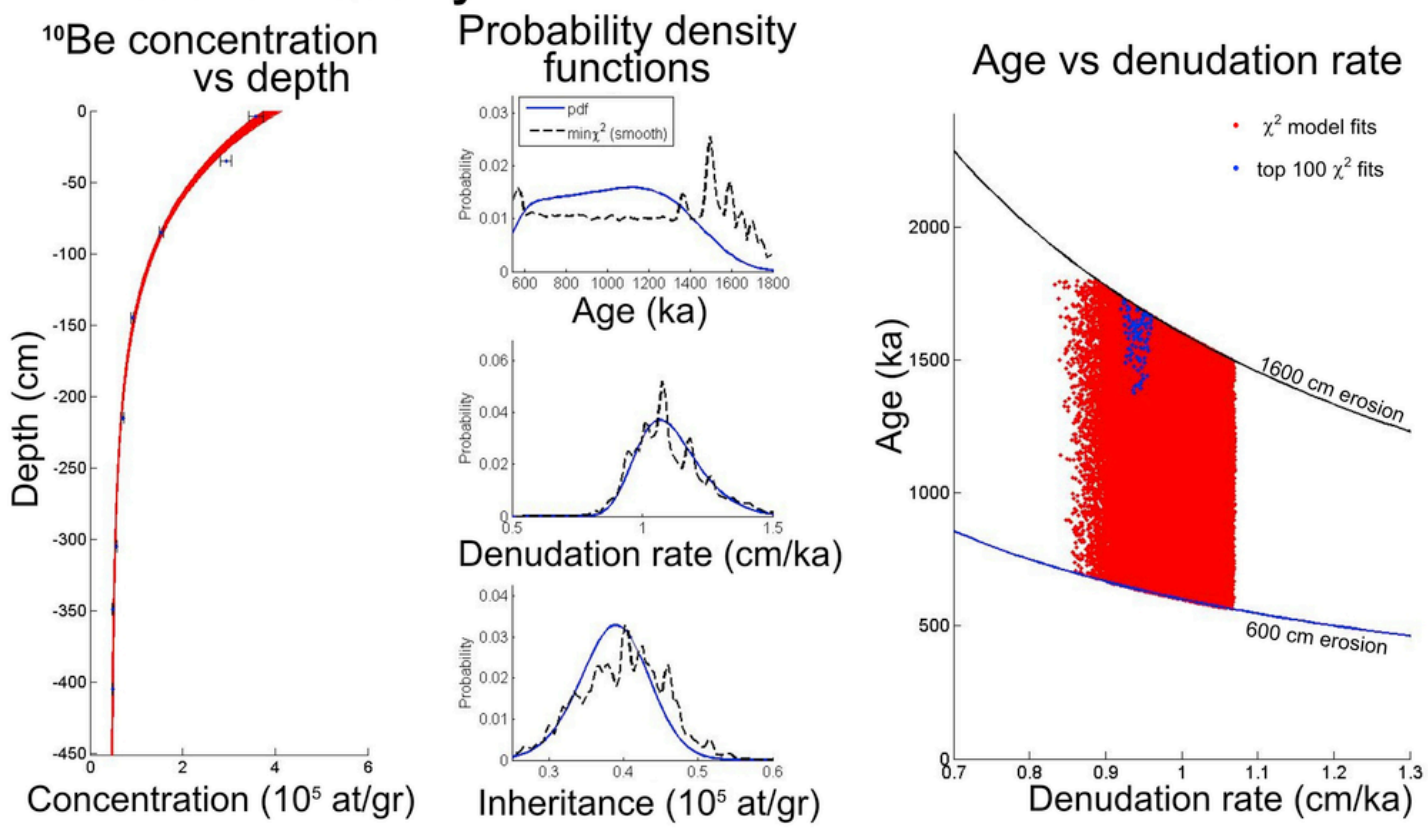

B Kender Hill ${ }^{10} \mathrm{Be}$ concentration vs depth
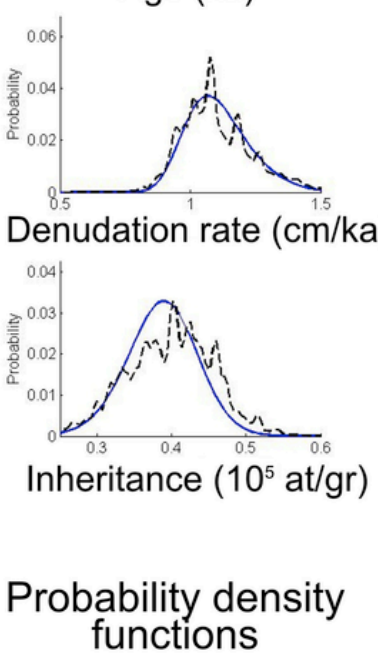

\section{Age vs denudation rate}
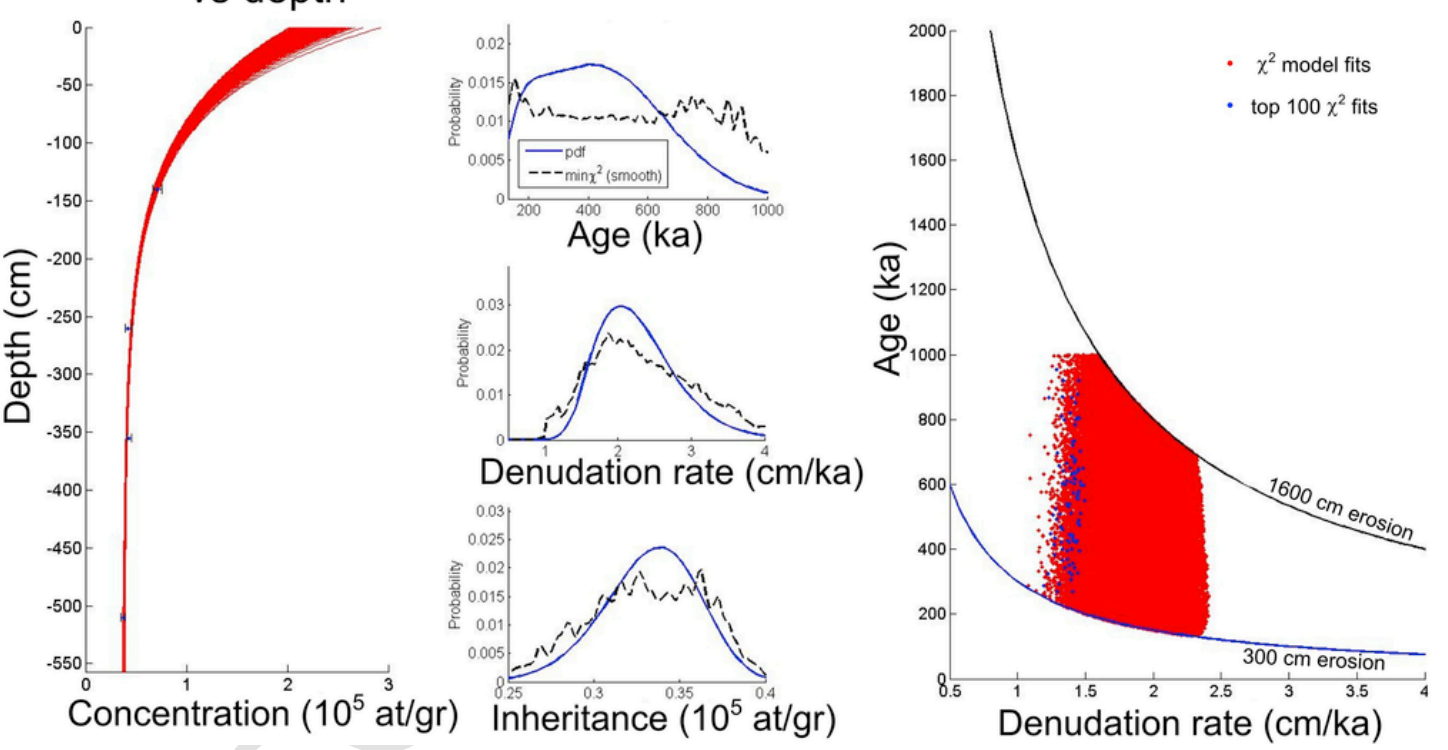

Fig. 9. Representative Monte Carlo depth profile simulation plots (Hidy et al., 2010) A: Betlehem Quarry, B: Kender Hill.

It is important to mention, that the actual sample depth was taken into account during CRN depth profile modelling as the uncertainties linked to the unknown variation in material thickness caused by eolian processes (denudation and sedimentation) would be as large as, or even larger than, the uncertainties linked to the measured sediment thickness values.

\subsection{Terrace $f Q 2 c$, Tata}

The surface of terrace fQ2c of the Által-ér creek at Tata $(\sim 143 \mathrm{~m}$ a.s.l. Fig. 1) is covered by a $\sim 5-8 \mathrm{~m}$ travertine layer (Scheuer and Schweitzer, 1988), which includes a $60-70 \mathrm{~cm}$ thick, horizontal fine sandy loess layer containing paleontological remains, Palaeolithic tools and artefacts belonging to the Homo sapiens neanderthalensis (Schwartz and Skoflek, 1982). As at Vértesszólös, the archaeological importance of this site (Vértes, 1964) highlighted it as an early target for numerical dating. First, a U/Th age of $70 \pm 20$ ka was proposed for the travertine from below the cultural layer (Pécsi, 1973); then, U/Th ages scattering around $100 \pm 15$ ka were suggested for the travertine above and below the cultural layer (Schwartz and Skoflek, 1982); and, 3). Finally, U/Th and ESR ages of $101 \pm 10 \mathrm{ka}$ and $127 \pm 6 \mathrm{ka}$, respectively, were determined for the travertine below the cultural layer and of $98 \pm 8$ ka and $81 \pm 16 \mathrm{ka}$, respectively, for the travertine above the cultural layer (Hennig et al., 1983). These data enabled the age of the cultural layer to be determined as around $\sim 100 \mathrm{ka}$. The terrace was considered to have been deposited not much earlier and was classified into level 
Table 6

Best constrained model solutions of the ${ }^{10} \mathrm{Be}$ depth profile simulator (Hidy et al., 2010). For simulation settings refer to Table 5 .

\begin{tabular}{llll}
\hline & $\begin{array}{l}\text { Exposure age } \\
(\mathrm{ka})\end{array}$ & $\begin{array}{l}\text { Denudation } \\
\text { rate } \\
(\mathrm{m} / \mathrm{Ma})\end{array}$ & $\begin{array}{l}\text { Inheritance }\left(10^{3} \text { at/ }\right. \\
\mathrm{g})\end{array}$ \\
\hline Betlehem Quarry & & & \\
Mean & 1133 & 9.9 & 40 \\
Median & 1141 & 10.0 & 40 \\
Mode & 1384 & 10.1 & 40 \\
Min. $\chi^{2}$ & 1632 & 9.4 & 42 \\
Bayesian most & 1115 & 10.8 & 39 \\
$\quad$ probable & 1342 & 12.2 & 43 \\
Bayesian $1 \sigma$ upper & 713 & 9.8 & 34 \\
Bayesian $1 \sigma$ lower & & & \\
Kender Hill & 496 & 18.7 & 33 \\
Mean & 485 & 18.7 & 33 \\
Median & 221 & 18.8 & 33 \\
Mode & 697 & 12.9 & 31 \\
Min. $\chi^{2}$ & 404 & 20.2 & 34 \\
Bayesian most & & & \\
$\quad$ probable & 652 & 27.9 & 36 \\
Bayesian $1 \sigma$ upper & 236 & 17.3 & 30 \\
Bayesian $1 \sigma$ lower & & & \\
\hline
\end{tabular}

IIb (e.g Pécsi, 1973), in spite of its higher elevation. We suggest that this terrace belongs to terrace $\mathrm{fQ} 2 \mathrm{c}$ of the revised system.

The paleomagnetic study of the travertine revealed a normal polarity, suggesting travertine precipitation during the Brunhes chron (<0.78 Ma; Lantos, 2004)

The fine sandy loess - fine sand layer provided numerous Late Pleistocene fossils (including e.g. Mammuthus primigenius, Coelodonta antiquitatis, Equus (Asinus) hydruntinus, Megaloceros giganteus, Cervus elaphus, Crocuta crocuta spelaea, Ursus spelaeus) along with a rich archaeological material (Kormos, 1912; Kretzoi, 1964). The fauna is transitional between the Süttő ( 130-115 ka) and Varbó ( 100-90 ka) local biochronological phases (Kretzoi, 1953; Pazonyi, 2006). This is in agreement with the U/Th and paleomagnetic data. Based on the absence of arctic elements within the fauna, a relatively warm, interglacial environment at the time of deposition is suggested (probably MIS5c; Pazonyi, 2011), in line with the sedimentological and magnetic susceptibility data (Ruszkiczay-Rüdiger and Bradák, 2005).

\subsection{Terraces $f Q 3 b$ and $f Q 2 b$, Nes\%mély}

The extent of terraces fQ2 $b$ and fQ3b is limited in the Gerecse Hills (Fig. 1; Csillag et al., 2018). In the north, close to the Danube, they are exposed in two adjacent abandoned sandpits (120 and $145 \mathrm{~m}$ a.s.l. respectively). In the upper outcrop (Neszmély Upper), the cross-bedded fluvial sand of the Danube was truncated by a local tributary of the Danube. The two sediments could be clearly distinguished in the field (Fig. 10B). The age determination of this terrace (LUM-124.2 and 124.3) and that of the incised creek sediments postdating the terrace (LUM-124.1) were also performed using the pIRIR ${ }_{290}$ technique on coarse-grain K-feldspar. In the lower outcrop (Neszmély Lower, Fig. $10 \mathrm{C}$ ) the exposed cross-bedded sand of the terrace fQ2b was sampled for pIRIR $_{290}$ dating (LUM-129.1, -129.2).

The pIRIR $_{290}$ signals of the five samples were not far from their saturation level (71-84\%), but the De values could be estimated accurately. Dose recovery ratios and residual doses were measured after $4 \mathrm{~h}$ bleaching on full sunshine (LUM-129.1-2) or $12 \mathrm{~h}$ changeable sunlight (LUM-124.1-3). Dose recovery ratios were $1.18 \pm 0.13$ on average, showing that the measured doses are slightly higher than the laboratory doses administered to these samples. But for feldspar a poor dose recovery ratio does not surely mean an inaccurate measurement of $D_{e}$ (Buylaert et al., 2012). Residual doses were about $6-10 \%$ of the natural doses. Fading experiments of the samples indicated relatively low fading rates or g-values, $1.19 \pm 0.2 \%$ /decade on average; therefore fading correction was not necessary. Overdispersion of the $\mathrm{D}_{\mathrm{e}}$ values was between 4.1 and $9.8 \%$ in the Neszmély Upper section, and higher, $13.4-18.1 \%$ in the Neszmély Lower section (Table 7). As the distribution of the $\mathrm{D}_{\mathrm{e}}$ values of the samples was more or less symmetric, their ages were calculated by their mean and CAM $\mathrm{D}_{\mathrm{e}}$ values as well, based on Galbraith et al. (1999). These ages are very similar to each other, the difference between the mean and CAM age of a sample does not reach $1.5 \%$. The pIRIR $_{290}$ CAM ages of terrace fQ3b at Neszmély Upper are $264 \pm 26$ ka and $301 \pm 32 \mathrm{ka}$ (Table 7).

The sample from the sedimentary body of the local tributary cutting into terrace fQ3b of the Danube was $148 \pm 13$ ka (Fig. 10B; LUM-124.1). The resulting age estimates of the cross-bedded sand samples of terrace fQ2b at Neszmély Lower were $98 \pm 7$ and $117 \pm 9$ ka (Fig. 10C, Table 7; LUM-129.1, -129.2).

\section{Discussion}

\subsection{Robust terrace age constraints using multiple age determination techniques}

The terrace ages determined by this study are summarised in Table 8 and Fig. 12. The results presented in this study show that paleontological and CRN terrace age estimates in the Hungarian part of the Danube valley mutually support each other, as do those of Rixhon et al. (2014), who used ${ }^{10} \mathrm{Be}$ depth profiles for terrace age determinations in the Amblève valley, France. On the other hand, Schaller et al. (2016) compared novel CRN-based terrace ages with previous, paleontologically and/or magnetostratigraphically constrained terrace chronologies along four European rivers. In three out of four systems, the CRN ages proved to be 2-3 times older than previous terrace age estimates. In this study, previous division into palaeontological zones of the terrace-related fauna assemblages was carefully revised, and up-to-date numerical ages were assigned to the mammal and gastropod-based relative chronologies. This approach is essential if conflicting age estimates are to be settled with confidence.

The combination of CRN and luminescence dating allows a more robust age determination (Viveen et al., 2012; Ruszkiczay-Rüdiger et al., 2016). Moreover, the joint application of these methods, together with the use of paleontological data enables the dating of subsequent terrace formation from Late Pliocene to Late Pleistocene times, a wider age range than using either the CRN or OSL methods alone.

\subsection{Different landscape evolution scenarios revealed by the analysis of}

${ }^{26} \mathrm{Al} /{ }^{10} \mathrm{Be}$ ratios at the highest terraces

The estimated terrace ages are summarised in Table 8 and Fig. 12 . Since the correlation of the U/Th ages of the travertines older than the last interglacial to other geochronological data at similar geomorphological position is not significant, they will not be considered in respect of terrace ages. Instead, U/Th data will be discussed in Section 5.5.

The ${ }^{26} \mathrm{Al} /{ }^{10} \mathrm{Be}$ burial duration of the highest, fQ9 terrace at Kópite Hill lies between $\sim 2.9 \pm 0.5 \mathrm{Ma}$ and $\sim 2.6 \pm 0.4 \mathrm{Ma}$, in agreement with the paleontological data. The performed modelling suggests that there was no significant hiatus between the terrace abandonment by the Danube and the onset of travertine precipitation. The modelled CRN burial duration does not depend on the duration of travertine aggradation, but chiefly on the post-burial denudation rate. In the following, a burial duration of $2.94 \pm 0.49 \mathrm{Ma}$ (model $4 \mathrm{~b}$ ) associated with a surface denudation rate of $\sim 10 \mathrm{~m} / \mathrm{Ma}$ is considered as the most probable age for terrace abandonment at the Kôpite site. This is statistically indistinguishable from the $2.91 \pm 0.19$ Ma KDE burial duration of the terrace associated with an $8 \pm 1 \mathrm{~m} / \mathrm{Ma}$ post-burial denudation rate 
Table 7

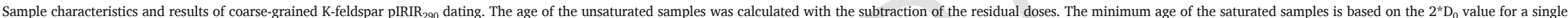

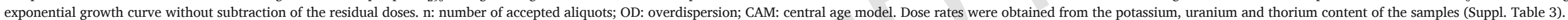

\begin{tabular}{|c|c|c|c|c|c|c|c|c|c|c|c|c|c|c|c|c|c|c|c|c|}
\hline \multirow[t]{2}{*}{ Location } & \multirow[t]{2}{*}{ Sample } & \multirow[t]{2}{*}{ Depth (m) } & \multirow[t]{2}{*}{ Grain size ( $\mu \mathrm{m})$} & \multirow[t]{2}{*}{$\mathrm{n}$} & \multirow[t]{2}{*}{ OD (\%) } & \multicolumn{3}{|c|}{ Dose rate (Gy/ka) } & \multicolumn{6}{|c|}{$\mathrm{D}_{\mathrm{e}} \mathrm{pIRIR}_{290}$ (Gy) } & \multicolumn{6}{|c|}{ pIRIR $_{290}$ age (ka) } \\
\hline & & & & & & & & & mean & & & CAM & & & mean & & & CAM & & \\
\hline \multirow[t]{3}{*}{ Kender Hill } & LUM-2281 & 3.70 & $150-200$ & 2 & & 2.38 & \pm & 0.14 & $>779$ & & & & & & $>327$ & & & & & \\
\hline & LUM-2282 & 6.00 & $150-212$ & 9 & 6.4 & 1.71 & \pm & 0.14 & 811.0 & \pm & 27.3 & 804.0 & \pm & 24.2 & 475.0 & \pm & 42.0 & 471.0 & \pm & 41.0 \\
\hline & LUM-2283 & 1.50 & $150-200$ & 11 & 7.8 & 2.33 & \pm & 0.14 & 31.2 & \pm & 1.1 & 31.1 & \pm & 1.1 & 13.4 & \pm & 1.0 & 13.4 & \pm & 1.0 \\
\hline \multirow[t]{2}{*}{ Betlehem Quarry } & LUM -2284 & 1.00 & $150-212$ & 2 & & 2.81 & \pm & 0.14 & $>975.6$ & & & & & & $>347$ & & & & & \\
\hline & LUM -2285 & 1.70 & $250-300$ & 2 & & 2.40 & \pm & 0.15 & $>877.0$ & & & & & & $>365$ & & & & & \\
\hline \multirow[t]{2}{*}{ Neszmély Lower } & LUM-129.1 & 1.25 & $100-150$ & 10 & 18.1 & 3.08 & \pm & 0.23 & 311.7 & \pm & 14.1 & 301.9 & \pm & 19.5 & 101.2 & \pm & 7.1 & 98.0 & \pm & 6.9 \\
\hline & LUM-129.2 & 6.70 & $100-150$ & 10 & 13.4 & 3.13 & \pm & 0.23 & 368.4 & \pm & 18.7 & 365.3 & \pm & 21.8 & 117.6 & \pm & 9.1 & 116.7 & \pm & 9.0 \\
\hline \multirow[t]{3}{*}{ Neszmély Upper } & LUM-124.1 & 5.50 & $100-150$ & 6 & 5.8 & 2.89 & \pm & 0.24 & 421.7 & \pm & 23.1 & 426.4 & \pm & 30.1 & 145.9 & \pm & 12.6 & 147.6 & \pm & 12.7 \\
\hline & LUM-124.2 & 3.80 & $100-150$ & 9 & 9.8 & 2.20 & \pm & 0.22 & 589.4 & \pm & 41.7 & 580.9 & \pm & 29.5 & 267.6 & \pm & 26.0 & 263.7 & \pm & 25.7 \\
\hline & LUM-124.3 & 4.60 & $100-150$ & 9 & 4.1 & 1.96 & \pm & 0.21 & 591.8 & \pm & 37.7 & 589.7 & \pm & 19.2 & 301.6 & \pm & 32.4 & 300.5 & \pm & 32.3 \\
\hline
\end{tabular}



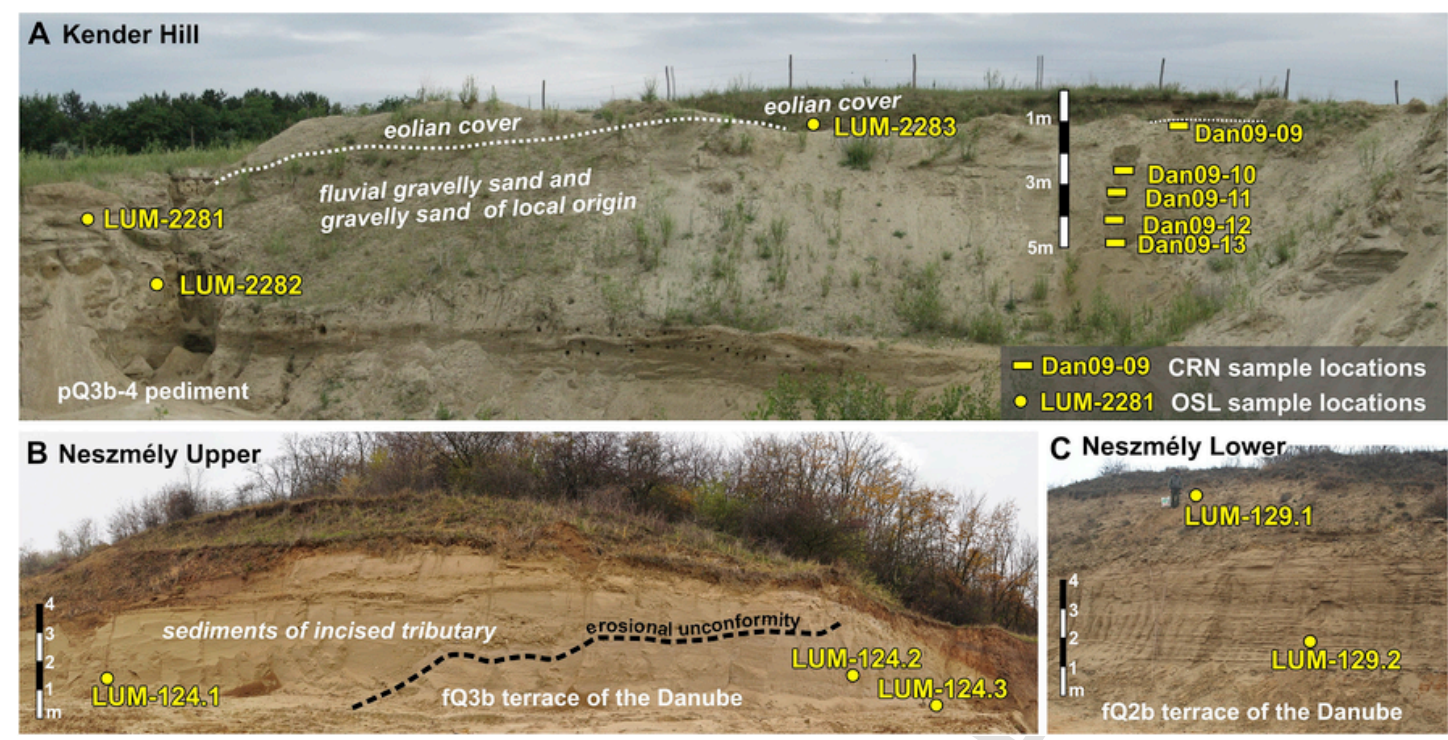

Fig. 10. Sample sites A: the sand pit exposing the fluvial sand cover of the pediment at the Kender Hill with the ${ }^{10} \mathrm{Be}$ depth profile and IRSL sample locations; B: Neszmély Upper: the fQ3b terrace with IRSL sample locations; C: Neszmély Lower: the fQ2b terrace with IRSL sample locations.

A
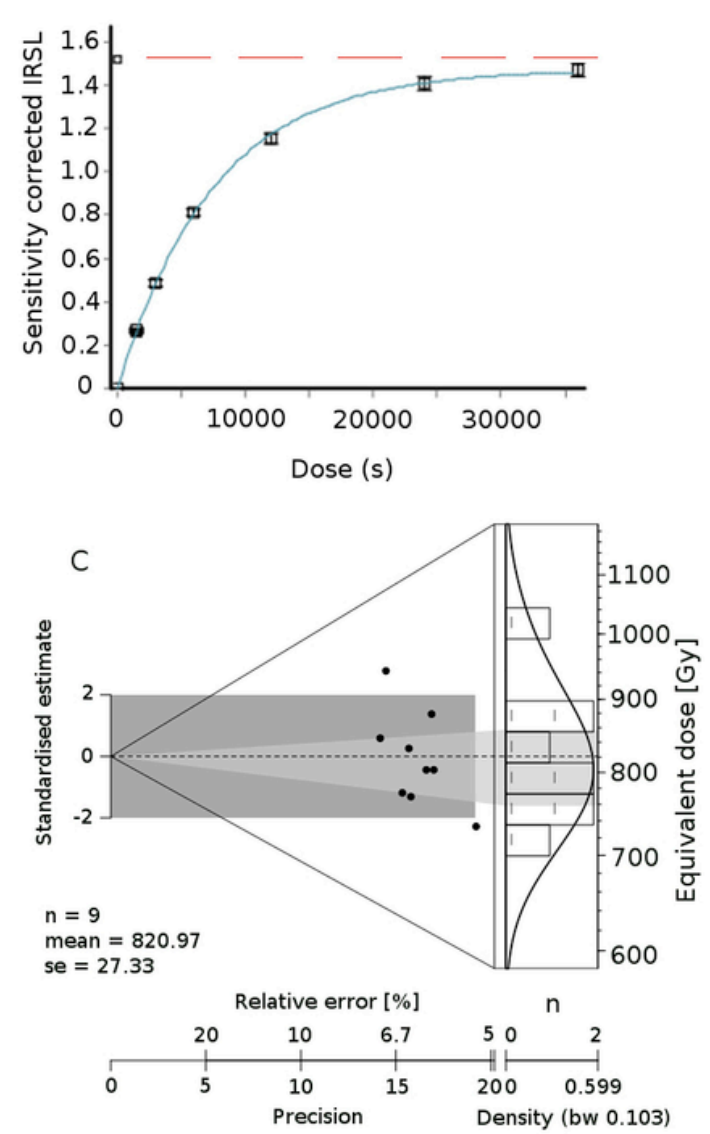

B

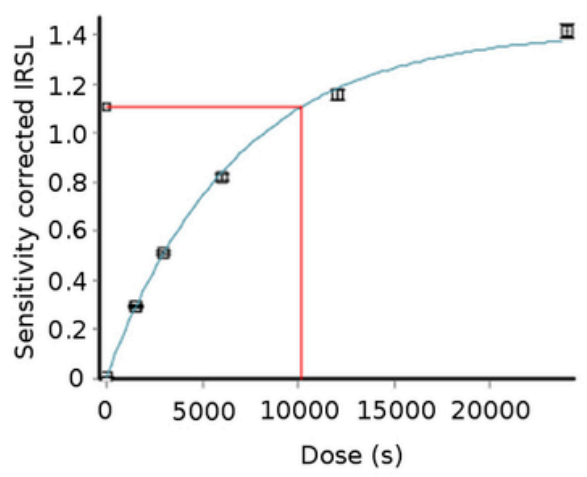

D

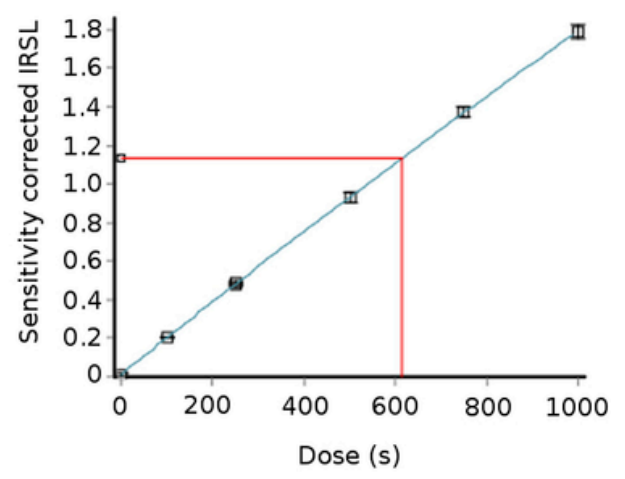

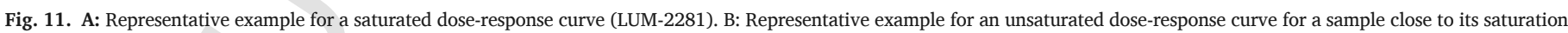

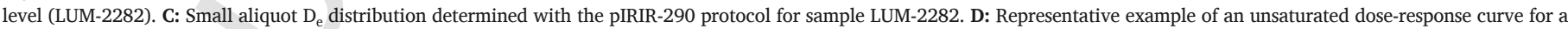
sample far from its saturation level (LUM-2283).

(model 1b), but larger uncertainty values better reflect the geological uncertainties at the location. This places the onset of the incision of the Danube at the Gerecse Hills as latest to Late Pliocene times.
The $2.32 \pm 0.14$ Ma KDE minimum CRN burial duration of the outcrop of the fQ7 terrace (Les Hill) agrees with the revised paleontological and magnetostratigraphic age of this horizon (2.4-2.6 Ma and 2.6-1.6 Ma, respectively). The suitability of minimum burial age esti- 
Table 8

Terrace ages in the Gerecse Hills quantified by this study, with relevant Marine Isotope Stages (MIS) of terrace formation. " $>$ " indicates minimum terrace age constrained only by the geochronological data on the terrace cover formation. MIS stages after Lisiecki and Raymo (2005). Travertine data are in Suppl. Table 2.

\begin{tabular}{|c|c|c|c|c|}
\hline Terrace & $\begin{array}{l}\text { Terrace age } \\
\text { (ka) }\end{array}$ & $\begin{array}{l}\text { Age of terrace } \\
\text { cover } \\
\text { travertine (ka) }\end{array}$ & $\begin{array}{l}\text { Age } \\
\text { determination } \\
\text { method }\end{array}$ & $\begin{array}{l}\text { MIS of } \\
\text { terrace } \\
\text { formation }\end{array}$ \\
\hline fQ9 & $2942 \pm 486$ & 7000-2000 & paleontology & $\begin{array}{l}\text { MG } 5 \text { - MIS } \\
97\end{array}$ \\
\hline fQ8 & & 2600-1950 & $\begin{array}{l}\text { CRN burial } \\
\text { duration } \\
\text { paleontology }\end{array}$ & $\begin{array}{l}>\text { MIS } 104 \\
-84\end{array}$ \\
\hline fQ7 & $2323 \pm 140$ & $2400-2000$ & $\begin{array}{l}\text { paleontology } \\
\text { CRN burial } \\
\text { duration }\end{array}$ & MIS 94 - 83 \\
\hline fQ5 & $\begin{array}{l}1100-780 \\
>713\end{array}$ & & $\begin{array}{l}\text { paleontology } \\
\text { CRN depth } \\
\text { profile }\end{array}$ & MIS 32-18 \\
\hline fQ4 & $>365$ & $500-400$ & $\begin{array}{l}\text { pIRIR }_{290} \\
\text { paleontology }\end{array}$ & $\begin{array}{l}>\text { MIS } \\
13-11\end{array}$ \\
\hline pQ4-3b & $\begin{array}{l}650-130 \\
404^{+248} /-168\end{array}$ & & $\begin{array}{l}\text { paleontology } \\
\text { CRN depth } \\
\text { profile }\end{array}$ & MIS 13-12 \\
\hline fQ3b & $\begin{array}{l}471 \pm 41 \\
301 \pm 32 \text { to } \\
264 \pm 26\end{array}$ & & $\begin{array}{l}\operatorname{pIRIR}_{290} \\
\operatorname{pIRIR}_{290}\end{array}$ & MIS 9-8 \\
\hline fQ2c & & $130-90$ & paleontology & $>$ MIS 6 \\
\hline fQ2b & $\begin{array}{l}117 \pm 9 \text { to } \\
98 \pm 7\end{array}$ & & pIRIR $_{290}$ & MIS 5e-b \\
\hline
\end{tabular}

mates (no post-burial CRN production) is limited to samples that have been completely shielded from cosmic irradiation for the greater part of their burial history. The sample depth of $5-6 \mathrm{~m}$ at the Les Hill violates this condition of complete shielding, unless a thickness of $>10 \mathrm{~m}$ of rock has recently been removed from above the sampled outcrop. The concordant KDE minimum burial age and independent age constraints confirm this scenario. The recent truncation of this rock thickness may have happened either due to gravitational sliding or ancient freshwater limestone quarrying. Our dataset suggests an Early Pleistocene age for this terrace level. It should be noted that the minimum burial age approach does not enable the quantification of the post-burial denudation rate.

The paleontological data of the Süttó travertine complex suggest an age range of 2-3 Ma for the formation of the travertine complex covering gravelly sediments at the elevation range of terraces fQ7 and fQ8. However, the low and variable ${ }^{26} \mathrm{Al} /{ }^{10} \mathrm{Be}$ ratios of these gravels suggest that this sediment may have been partly or entirely re-deposited from older horizons, a scenario supported by geomorphological and sedimentological observations. The 2-3 Ma minimum age of travertines deposited at the elevation range of these terraces is in line with the regional landscape evolution depicted by the other study sites.

\section{3. ${ }^{10} \mathrm{Be}$ depth profiles in combination with IRIR $_{290}$ ages and paleontological data, at the middle terraces}

The ${ }^{10} \mathrm{Be}$ depth profile of the fQ5 level (Betlehem Quarry) is at steady state. Therefore, only a minimum exposure age of $>713$ ka can be determined with confidence. This estimate agrees with the assumed age of the gastropod fauna of this terrace. The pIRIR $_{290}$ method was only capable of providing minimum ages ( $>347$ and $>365 \mathrm{ka}$ ). Both numerical ages are in line with the paleontological age range of $1.1 \mathrm{Ma}$ to $0.78 \mathrm{Ma}$ for this terrace.

Results of the combined application of $\mathrm{a}^{10} \mathrm{Be}$ depth profile and the pIRIR $_{290}$ methods applied to the pQ4-3b pediment surface (Kender Hill) are in agreement, and yielded ages of $404^{+248} /{ }_{-168}$ ka and $471 \pm 41 \mathrm{ka}$, respectively. These numerical ages are also line with the Middle Pleistocene paleontological age of the sediment (650-130 ka), and help to narrow the possible age range. The uncertainties associated with the CRN depth profile exposure age are linked to the unfavourable conditions encountered in the upper part of the profile, which has been truncated, removing the most relevant CRN inventory for age determination.

The revised paleontological age of the travertine cover of the fQ4 terrace at Vértesszőlós is $450 \pm 50 \mathrm{ka}$, which is in agreement with the age of the associated fQ3b-4 pediment. The formation of the fQ4 terrace might be tentatively linked to MIS 12 (Table 8).

The occurrence of the fQ4 terrace in the western Gerecse Hills is very limited. Most probably terrace formation was followed by a strong denudation event (as indicated by the almost complete absence of the terrace material at Vértesszólős), and the geomorphological horizon was preserved only where it was protected by travertine.

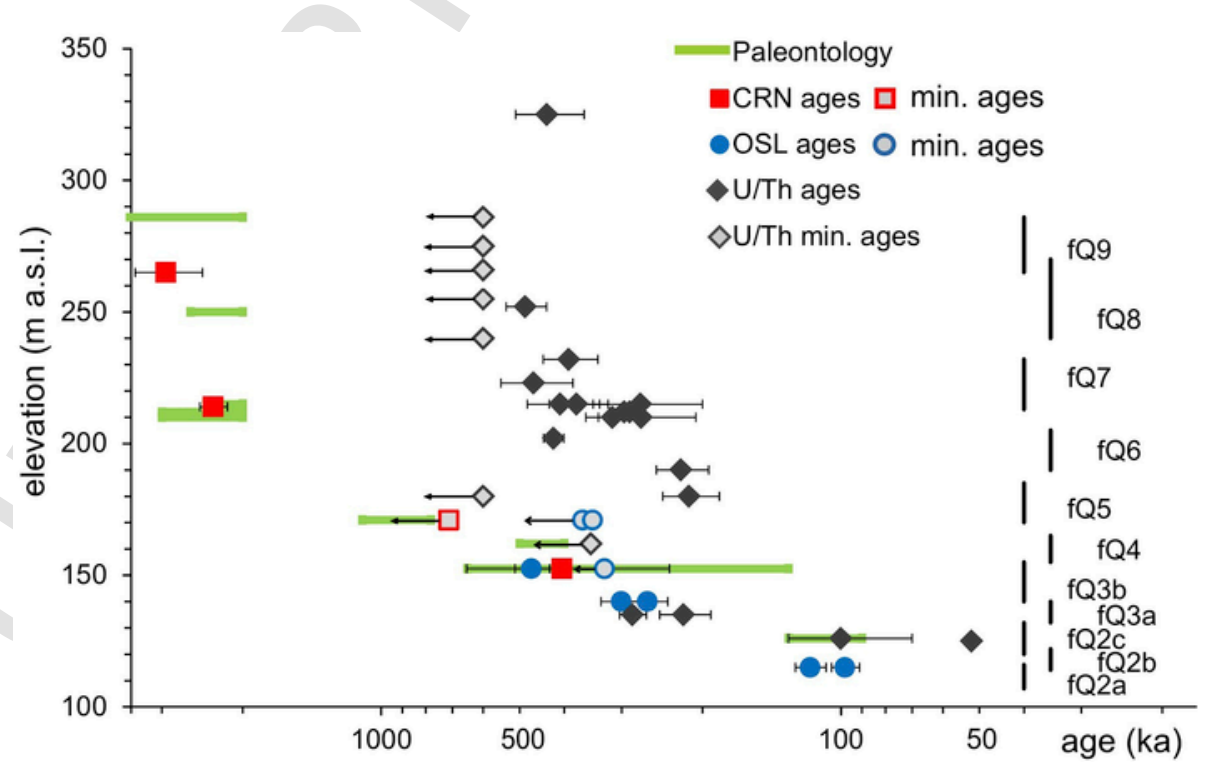

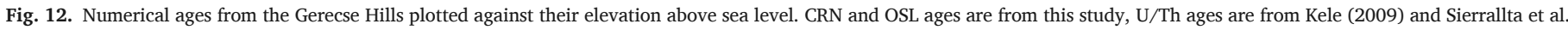
(2010). Black bars are the elevation ranges of the fQ2a-fQ9 terraces. Note that the $\mathrm{x}$ axis is logarithmic. 
The upper part and the original surface of the sandpits Neszmély Upper and Lower were largely uncertain, therefore these were not targeted by CRN depth profiles only by luminescence dating. The pIRIR ${ }_{290}$ age of terrace fQ3b (Neszmély Upper) is between $301 \pm 32$ ka and $264 \pm 26$ ka. No data are available for terrace fQ3a. Its formation can only be placed between $\sim 250 \mathrm{ka}$ and $\sim 150$ ka bracketed by data from the horizons above and below it.

\subsection{Low terraces: paleontological, pIRIR ${ }_{290}$ and $U / T h$ ages in agreement}

The $148 \pm 13$ ka pIRIR 290 age of the sediment belonging to a creek incised into terrace fQ3b (at Neszmély Upper) suggests that it was active during the formation of horizon fQ2c, dated at $143 \pm 10 \mathrm{ka}$ in the GTT (pIRIR $_{290}$; Ruszkiczay-Rüdiger et al., 2016). The travertine covering the terrace fQ2c (Tata) was U/Th dated at $\sim 100 \mathrm{ka}$, and its revised mammal fauna suggest an age between 130 and $90 \mathrm{ka}$, which is in agreement with the pIRIR 290 age of the underlying terrace level. At this site, the U/ Th based ages agree with the geomorphological position and the paleontological data.

The pIRIR 290 dating of the lowest horizon of the study area (fQ2b, Neszmély Lower) leads to burial duration estimates ranging from $98 \pm 7$ and $117 \pm 9 \mathrm{ka}$, the younger age corresponding to the upper part of the profile. This is in agreement with the $91 \pm 9 \mathrm{pIRIR}_{290}$ age of the same horizon in the GTT (Ruszkiczay-Rüdiger et al., 2016).

\subsection{Inconsistencies in the U/Th age data of travertines associated with terrace horizons}

The earliest chronological constraints on travertine deposits had their origins in paleontological studies (Jánossy and Krolopp, 1981; Jánossy, 1986; Krolopp, 2004). The first numerical ages were obtained following the progress of the U/Th and ESR methods (Pécsi and Osmond, 1973; Schwartz and Skoflek, 1982; Hennig et al., 1983; Schwartz and Latham, 1984), and from paleomagnetic studies (Latham and Schwarcz, 1990; Lantos, 2004). Paleontological and paleomagnetic studies suggested an Early Pleistocene or even older age for some travertines deposited at the highest elevations, and a Middle to Late Pleistocene age for those deposited in lower positions. Recent U/Th dating studies at several travertine complexes of the Gerecse Hills (Kele, 2009; Sierrallta et al., 2010) suggest Middle to Late Pleistocene ages, except for some locations dated as older than the $600 \mathrm{ka}$ limit of the U/Th method (Suppl Table 2). In contradiction to the initial hypothesis, according to which travertine precipitation occurred at or close to the former base level (Pécsi et al., 1984; Schulte et al., 2008; Zentmyer et al., 2008. Wang et al., 2017), U/Th travertine ages in the Gerecse Hills display a poor age-elevation relationship (Fig. 12, for data refer to Suppl. Table 2). Besides, as demonstrated in previous sections, in several cases the relatively young travertine ages are in contradiction to other chronological methods, which suggest older age for the travertines at high altitude. The observed discrepancy suggests that the U/Th ages of the Gerecse Hills travertine are biased relative to their precipitation ages. This is puzzling as several studies in other parts of the world have claimed good agreement between independently dated terraces and the $\mathrm{U} / \mathrm{Th}$ ages of terrace-covering travertines.

Wang et al. (2017) published concordant Holocene and late Pleistocene OSL terrace and U/Th ages for travertine covering terraces in the Sutlej River valley (Tibet. Zentmyer et al. (2008) have dated a travertine precipitated on a former floodplain in Tibet at $~ 11.6 \mathrm{ka}$, and derived a reasonable incision rate $(1.6 \mathrm{~mm} / \mathrm{yr})$. In a setting approximating the Pannonian Basin, Antoine et al. (2007) successfully determined an age falling in the last interglacial ( $120 \mathrm{ka})$ for calcareous tufa deposited in the Somme valley (France) using the U/Th method, and calculated an uplift rate in agreement with the independently derived uplift rate of $\sim 0.06 \mathrm{~mm} / \mathrm{yr}$ of the area. In these studies freshwa- ter limestone precipitation was obviously linked to the active floodplains along the river, and the age determination was restricted to the last glacial cycle. Finally, Schulte et al. (2008) U/Th dated the formation of a travertine platform on the Aguas River (Southern Spain) between $\sim 169$ and $26 \mathrm{ka}$, in agreement with geomorphological and palynological data. Scotti et al. (2014) also dated terrace formation in the Iberian Chain using the U/Th ages of calcareous tufas deposited on strath terraces between $\sim 105$ and $\sim 40 \mathrm{ka}$.

In the Gerecse Hills travertine formation could not be linked to a floodplain environment. At most locations travertines show a tetarata structure (Schréter, 1953; Scheuer and Schweitzer, 1988), implying that the carbonate-rich waters were welling up well above base level. At that time, they flowed down the hillslopes and along pre-existing valleys from their discharge point. Accordingly, travertine precipitation took place in a gently sloping environment in the form of spring-mounds and tetarata systems with ponds of lacustrine environment (Török et al., 2017). Nevertheless, the U/Th age of $100 \mathrm{ka}$ of the travertine covering terrace fQ2c at Tata is in line with its OSL age and with the palaeontological record. This is within the late Pleistocene time span, where previous studies successfully used the U/Th method for terrace age determination. Unfortunately, any U/Th ages older than the last interglacial proved to be younger than the age of the relevant horizon suggested by other dating methods (OSL, CRN, paleontology, magnetostratigraphy).

In their study on the U/Th dating of travertines and aragonite veins impregnating old terraces of the Allier River (France), Rihs et al. (2000) found evidence for sub-surface travertine precipitation in periods of interglacial and interstadial climate, as well as the formation of deeper aragonite veins during glacial phases. They distinguished three main episodes of hydrothermal deposition between 253 and $8 \mathrm{ka}$. In the same study area Veldkamp et al. (2004) have dated further travertine units using the U/Th method and reported similar evidence. Their conclusion was that of an indeterminate relationship between incision and travertine precipitation. Soligo et al. (2002) came to similar conclusions $\mathrm{U} / \mathrm{Th}$ dating travertines in the Velino Valley (Italy). They determined that besides the climatic influence, travertine precipitation was strongly affected by tectonic activity. Therefore, at locations undergoing complex geological evolution, the correlation of terrace elevation and associated travertine ages in order to derive incision/uplift rates is far from straightforward.

In the Gerecse Hills, relatively young travertine ages, as compared to the underlying terrace, may be explained by karst-water springs above base level. Indeed it has been demonstrated that the locations of recent karst-water springs are not only governed by the base level fluctuations, but also by gravity driven regional groundwater flow (Mádl-Szőnyi and Tóth, 2015). Therefore, the deposition of travertine a relatively long time after terrace abandonment can be explained if freshwater limestone precipitation occurred well above the base level. In such a scenario, the suitability of travertine U/Th age data is very limited for the quantification of river incision, even if it is precise and accurate for the age determination of the travertine formation itself.

On the other hand, with regard to travertines older then Late Pleistocene, mammalian fossils described from within the travertine bodies suggest older age than those suggested by the U/Th data for the travertine units, while they agree with magnetostratigraphy and CRN ages. It is more difficult to reveal the reason for such a discrepancy, as it may indicate that the measured U/Th ratios do not reflect the age of travertine precipitation. This assumption may be supported by U/Th ages with no age-depth relationship along a profile, and which contradict the stratigraphic order within the travertine (Veldkamp et al., 2004; Sierrallta et al., 2010).

Although establishing the relevance of the U/Th data in the study area is not the main thrust of this study, two possible explanations may be proposed for the observed discrepancies: 1 ) The thorium contamina- 
tion of the travertine may have been more significant than accounted for; 2) the travertines of the study area may have behaved as an open system and received additional Uranium during calcite recrystallization. A combination of these processes may yield U/Th ages younger than the effective travertine precipitation age, and as well as inverse ages relative to the stratigraphy within a travertine body (Scholz et al., 2014).

In conclusion, we suggest that in areas experiencing a relatively low uplift and complex interaction between the structure and climate oscillations, the U/Th method is not necessarily suitable for the age determination of the travertine deposits and related terraces. In the study area, the U/Th ages of travertines associated with terraces older than Late Pleistocene are scattered and are mostly biased towards younger ages. Nevertheless, in other geological and geographical settings, the U/ Th age determination of travertine, if applied with caution, may serve as suitable tool for the quantification of river incision and surface uplift.

\subsection{Denudation rates constrained using depth profiles}

In landscapes undergoing denudation, the CRN saturation level of long-lived radionuclides such as ${ }^{10} \mathrm{Be}$ and ${ }^{26} \mathrm{Al}$ depends on the surface denudation rate. Therefore, depth profiles with saturated CRN concentrations are well suited to the determination of surface denudation rates (Fig. 9A and B.; Siame et al., 2004; Hidy et al., 2010; Ruszkiczay-Rüdiger et al., 2016; Wüthrich et al., 2017). This allowed the quantification of a denudation rate of $11^{+1} /{ }_{-1} \mathrm{~m} / \mathrm{Ma}$ for the terrace at the Betlehem Quarry and of $20^{+8} /{ }_{-3} \mathrm{~m} / \mathrm{Ma}$ for the Kender Hill, whose gently dipping pediment surface is more exposed to surface denudation.

These results, together with the denudation rates between 6 and $11 \mathrm{~m} / \mathrm{Ma}$ constrained also by four saturated depth profiles on the fQ6 terrace in the GTT (Ruszkiczay-Rüdiger et al., 2016) are typical on flat, gravel capped or travertine-covered terrace surfaces in the northwestern part of the Pannonian Basin (and may increase up to $20 \mathrm{~m} / \mathrm{Ma}$, at sloping gently sloping surfaces like the fQ4-3b pediment).

These values are somewhat higher than denudation rates between $3 \pm 1$ and $8 \pm 2 \mathrm{~m} / \mathrm{Ma}$ assessed using depth profiles at the Segre River terraces in Spain (Stange et al., 2013). On the other hand, they reflect lower surface denudation rates than those of glacial sediments on the Swiss Plateau ( 15-63 m/Ma; Wüthrich et al., 2017). The denudation rates of the study area and the neighbouring GTT are also lower than the average of cosmogenic in situ ${ }^{10} \mathrm{Be}$ denudation rates from outcrops in the temperate climate zone $(25 \pm 2.5 \mathrm{~m} / \mathrm{Ma}$; Portenga and Bierman, 2011), suggesting relatively slow denudation of the Danube terraces.

Another important outcome of the ${ }^{10} \mathrm{Be}$ depth profile modelling is that the applicability of depth profiles is limited for terraces in or above the age range of $0.6-1 \mathrm{Ma}$, except in cases where surface denudation is negligible or very slow $(\ll 1 \mathrm{~m} / \mathrm{Ma})$. Increasing the depth of the profile may help to increase the datable time range (Braucher et al., 2009).

The presented results support the view that CRN depth profiles are a robust way of determining surface denudation rates (Siame et al., 2004; Braucher et al., 2009; Hidy et al., 2010; Ruszkiczay-Rüdiger et al., 2016, Wüthrich et al., 2017). This is in contrast to conclusions of Akçar et al. (2014) and Claude et al. (2017), who suggested that the erosion rate statistics of the depth profile simulator could not be used to derive a convincing value for erosion rate for the Swiss Deckenschotter. In order to obtain a definite value for the exposure duration of the sediments they sampled, strict constraints had to be placed on surface denudation. Therefore, a narrow, user defined window for total denudation and denudation rate was used in their Monte Carlo simulations.

By way of contrast, here, as a first step, the calculation of the integration times at surface and at depth is suggested to estimate the site- specific datable time range. Next, Monte Carlo simulations with no restrictions are followed by the use of a geologically constrained, but sufficiently wide window for surface denudation values. Using the Bayesian statistics the denudation rates are constrained by the model using the measured CRN concentrations.

As ${ }^{10} \mathrm{Be}$ depth profile dating is cost- and labour-intensive, it is hoped that the conclusions reached here will assist researchers in the assessment before sampling of whether the ${ }^{10} \mathrm{Be}$ depth profile dating of the targeted sedimentary succession is well suited for the age determination of a geomorphological horizon or only for the estimation of a minimum exposure age with a well-defined denudation rate.

\section{Conclusions}

The modelling of CRN concentrations combined with luminescence dating and revised paleontological data proved to be a robust method of determining terrace age. This study provided a terrace chronological dataset for the Hungarian Danube valley from Late Pliocene to Late Pleistocene times, a wider age range than could be achieved using either just the CRN or OSL methods alone. According to the CRN burial age of the highest terrace, the incision of the Danube River was already ongoing during the late Pliocene, which is the oldest numerical terrace age in the region. Development of four terrace horizons was placed to the Early Pleistocene (2.6-0.8 Ma). Four terraces were dated to the Middle Pleistocene $(0.8-0.13 \mathrm{Ma})$ and formation of two occurred during the Late Pleistocene (130-11 ka). CRN, OSL, revised paleontological ages and the magnetostratigraphic position of the terraces are internally consistent, while U/Th ages of travertines covering and/or impregnating the terrace material are scattered and significantly offset towards younger ages. Accordingly, these data were omitted from the interpretation of terrace evolution.

Besides age determination, the modelling of the ${ }^{26} \mathrm{Al}$ and ${ }^{10} \mathrm{Be}$ concentrations of the sampled terraces provided additional data on landscape evolution. For instance: (1) the absence of a major hiatus between terrace abandonment and travertine precipitation at the highest level; (2) the redeposited origin gravelly material formerly considered as terrace sediment of the Danube River; and (3) the recent removal of a considerable thickness of material from above a dated outcrop.

This study reinforces the impression that ${ }^{10} \mathrm{Be}$ depth profiles are well suited for the quantification of the surface denudation rate, even if the CRN concentrations are saturated. The time needed to reach the saturation level of CRN concentrations increases if the denudation rate is slower and if the sampled profile is deeper. We suggest that depth profiles of at least 5-6 $\mathrm{m}$ depth in undisturbed sedimentary sections affected by slow surface denudation are the best targets for ${ }^{10} \mathrm{Be}$ depth profile dating in the time range of the Middle Pleistocene or younger.

\section{Acknowledgements}

Our research was supported by several grants of the National Research, Development and Innovation Office of Hungary (NKFIH-OTKA $83610,100315,81530,113013,83400,106197,124807)$; by the French-Hungarian PHC Balaton-Tét projects (17318 RM/FR-32/2007; 27851UM/TÉT_11-2-2012-0005), and by the Bolyai Postdoctoral Research Programme of the Hungarian Academy of Sciences. The ASTER AMS national facility (CEREGE, Aix en Provence), where the 10Be and $26 \mathrm{Al}$ measurements were performed, was supported by the INSU,CNRS, the ANR through the "Projets thématiques d'excellence" program for the "Equipements d'excellence" ASTER-CEREGE action, and the IRD. We are grateful to Bálint Szappanos, Ágnes Török, András Markó and Sándor Kele for the useful discussions. Thanks to Attila Nagy, Mariann Török-Sinka and the LIAG (Hannover) for gamma spectrometry measurements, Judit Füri, Miklósné Bátori and Zsolt Horváth for their help in the OSL sample preparation, measurements and the water content 
determination. We are grateful for the comments and suggestions of Gilles Rixhon and an anonymous reviewer, which helped a lot to improve the manuscript.

\section{Appendix A. Supplementary data}

Supplementary data related to this article can be found at https:// doi.org/10.1016/j.quageo.2018.08.003.

\section{Uncited references}

Ujházy et al., 2003.

\section{References}

Aitken, M.J., 1998. An Introduction to Optical Dating. The Dating of Quaternary Sediments by the Use of Photon-stimulated Luminescence. Oxford University Press, Oxford, $267 \mathrm{pp}$.

Akçar, N., Ivy-Ochs, S., Alfimov, V., Claude, A., Graf, H.R., Dehnert, A., Kubik, P.W., Rahn, M., Kuhlemann, J., Schlüchter, C., 2014. The first major incision of the Swiss Deckenschotter landscape. Swiss J. Geosci. 107, 337-347.

Anders, M.D., Pederson, J.L., Rittenour, T.M., Sharp, W.D., Gosse, J.C., Karlstrom, K.E., Crossey, L.J., Goble, R.J., Stockli, L., Yang, G., 2005. Pleistocene geomorphology and geochronology of eastern Grand Canyon: linkages of landscape components during climate changes. Quat. Sci. Rev. 24, 2428-2448.

Anderson, R.S., Repka, J.L., Dick, G.S., 1996. Explicit treatment of inheritance in dating depositional surfaces using in situ ${ }^{10} \mathrm{Be}$ and ${ }^{26} \mathrm{Al}$. Geology $24,47-51$.

Antoine, P., Limondin Lozouet, N., Chaussé, C., Lautridou, J.-P., Pastre, J.-F., Auguste, P., Bahain, J.-J., Falguéres, C., Galehb, B., 2007. Pleistocene fluvial terraces from northern France (Seine, Yonne, Somme): synthesis, and new results from interglacial deposits. Quat. Sci. Rev. 26, 2701-2723.

Antón, L., Rodés, A., De Vicente, G., Pallàs, R., Garcia-Castellanos, D., Stuart, F.M., Braucher, R., Bourlès, D., 2012. Quantification of fluvial incision in the Duero Basin (NW Iberia) from longitudinal profile analysis and terrestrial cosmogenic nuclide concentrations. Geomorphology 165-166, 50-61.

Arsuaga, J.L., Martínez, I., Arnold, L.J., Aranburu, A., Gracia-Téllez, A., Sharp, W.D., Quam, R.M., Falguères, C., Pantoja-Pérez, J., Bischoff, J., Poza-Rey, E., Parés, J.M., Carretero, J.M., Demuro, M., Lorenzo, C., Sala, N., Martinón-Torres, M., García, N., Alvázar de Velasco, A., Cuenca-Bescos, G., Gómez-Olivencia, A., Moreno, D., Pablos, A., Shen, C.C., Rodriguez, L., Ortega, A.I., García, R., Bonmatí, A., Bermúdez de Castro, J.M., Carbonell, E., 2014. Neandertal roots: cranial and chronological evidence from Sima de los Huesos. Science 344 (6190), 1358-1363.

Bender, A.M., Amos, C.B., Bierman, P., Rood, D.H., Staisch, L., Kelsey, H., Sherrod, B., 2016. Differential uplift and incision of the Yakima River terraces, central Washington State. J. Geophys. Res.: Solid Earth 121, 365-387. https://doi.org/10.1002/ 2015JB012303.

Bradák, B., Kis, , Markó, A., 2013. Alsó- és középső-paleolitikus régészeti lelőhelyek ősföldrajzi viszonyai a Gerecse peremén: áttekintés Vértesszőlős, Tata és Tokod példáján. In: Kis, É. (Ed.), Terresztrikus Domborzatfejlődés a Vértes És a Gerecse Környezetében a Bérbaltaváriumtól a Holocénig. MTA CSFK FKI, Budapest, pp. 99-119.

Braucher, R., Brown, E.T., Bourlés, D.L., Colin, F., 2003. In situ produced ${ }^{10}$ Be measurements at great depths: implications for production rates by fast muons. Earth Planet Sci. Lett. 211, 251-258.

Braucher, R., Del Castillo, P., Siame, L., Hidy, A.J., Bourles, D.L., 2009. Determination of both exposure time and denudation rate from an in situ-produced ${ }^{10} \mathrm{Be}$ depth profile: a mathematical proof of uniqueness. Model sensitivity and applications to natural cases. Quat. Geochronol. 4, 56-64.

Braucher, R., Merchel, S., Borgomano, J., Bourles, D.L., 2011. Production of cosmogenic radionuclides at great depth: a multi element approach. Earth Planet Sci. Lett. 309, $1-9$.

Braumann, S., Neuhuner, S., Fiebig, M., Schaefer, J.M., Hintersberger, E., Lüthgens, C., 2018. Challenges in constraining ages of fluvial terraces in the Vienna Basin (Austria) using combined isochron burial and pIRIR225 luminescence dating. Quat. Int.(in press).

Buylaert J.-P., Jain, M., Murray, A.S., Thomsen, K.J., Jain, M. 2009. Testing the potential of an elevated temperature IRSL signal from K-feldspar. Radiation Measurements 44, 560-565. Buylaert, J.-P., Jain, M., Murray, A.S., Thomsen, K.J., Thiel, C., Sohbati, R., 2012. A robust feldspar luminescence dating method for Middle and Late Pleistocene sediments. Boreas 41, 435-451.

Çiner, A., Dogan, U., Yıldırım, C., Akcar, N.S., Alfimov, I.-O.V., Kubik, P.W., Schlüchter, C., 2015. Quaternary uplift rates of the Central Anatolian plateau, Turkey: in-sights from cosmogenic isochron-burial nuclide dating of the Kızılırmak River terraces. Quat. Sci. Rev. 107, 81-97.

Cherdintsev, V.V., Kazachevski, I.V., 1990. Absolute date of the travertine samples. In: Kretzoi, M., Dobosi, V. (Eds.), Vértesszőlős - Site, Man and Culture. Budapest. p. 547.

Claude, A., Akçar, N., Ivy-Ochs, S., Schlunegger, F., Kubik, P.W., Dehnert, A., Kuhlemann, J., Rahn, M., Schlüchter, C., 2017. Timing of early quaternary gravel accumulation in the Swiss alpine foreland. Geomorphology 276, 71-85.
Cohen, K.M., Gibbard, P., 2016. Global Chronostratigraphical Correlation Table for the Last 2.7 Million Years, v. 2016a. Subcommission on Quaternary Stratigraphy. International Commission on Stratigraphy, Cambridge http://www.stratigraphy.org/upload/ QuaternaryChartExplanation.pdf

Csillag, G., Fodor, L., Ruszkiczay-Rüdiger, Zs, Lantos, Z., Thamóné Bozsó, E., Babinszki, E., Szappanos, B., Kaiser, M., 2018. Fluvial, fluvial-proluvial, proluvial formations. In: In: Budai, T. (Ed.), Geology of the Gerecse Mountains. Mining and Geological Survey of Hungary, Budapest, vols. 131-168, ISBN: 978-963-671-312-6pp. 342-368.

DeLong, S.B., Arnold, L.J., 2007. Dating alluvial deposits with optically stimulated luminescence, AMS ${ }^{14} \mathrm{C}$, and cosmogenic techniques, western Transverse Ranges, California, USA. Quat. Geochronol. 2, 129-136.

Dombrádi, E., Sokoutis, D., Bada, G., Cloetingh, S., Horváth, H., 2010. Modelling recent deformation of the Pannonian lithosphere: lithospheric folding and tectonic topography. Tectonophysics 484 (1-4), 103-118.

Dunai, T.J., 2010. Cosmogenic Nuclides. Principles, Concepts and Applications in the Earth Surface Sciences. Cambridge Univ Press, New York, 187.

Erlanger, E.D., Granger, D.E., Gibbon, R.J., 2016. Rock uplift rates in South Africa from isochron burial dating of fluvial and marine terraces. Geology 40/11, 1019-1022.

Fejfar, O., Heinrich, W.-D., Pevzner, M.A., Vangengeim, E.A., 1997. Late Cenozoic sequences of mammalian sites in Eurasia: an updated correlation. Palaeogeogr. Palaeoclimatol. Palaeoecol. 133, 259-288.

Ferretti, M.P., 2003. Structure and evolution of mammoth molar enamel. Acta Palaeontol. Pol. 48/3, 383-396.

Ferretti, M.P., 2008. Enamel structure of Cuvieronius hyodon (Proboscidea, Gomphotheriidae) with a discussion on enamel evolution in Elephantoids. J. Mamm. Evol. 15, 37-58.

Fodor, L., Bada, G., Csillag, G., Horváth, E., Ruszkiczay-Rüdiger, Zs, Palotás, K., Síkhegyi, F., Timár, G., Cloetingh, S., Horváth, F., 2005. An outline of neotectonic structures and morphotectonics of the western and central Pannonian Basin. Tectonophysics 410 (1-4), 15-41.

Fodor, L., Kercsmár, Zs, Kövér, Sz, 2018. Structure and deformation phases of the Gerecse. In: In: Budai, T. (Ed.), Geology of the Gerecse Mountains. Mining and Geological Survey of Hungary, Budapest, vols. 169-208, ISBN: 978-963-671-312-6pp. 370-386.

Galbraith, R.F., Roberts, R.G., Laslett, G.M., Yoshida, H., Olley, J.M., 1999. Optical dating of single and multiple grains of quartz from Jinmium rock shelter, northern Australia: part I, experimental design and statistical models. Archaeometry 41/2, 339-364.

Gábris, Gy, 1994. Pleistocene evolution of the Danube in the carpathian basin. Terra. Nova 6, 495-501.

Gábris, Gy, Nádor, A., 2007. Long-term fluvial archives in Hungary: response of the Danube and Tisza rivers to tectonic movements and climatic changes during the Quaternary: a review and new synthesis. Quat. Sci. Rev. 26, 2758-2782.

Gasparik, M., 2001. Neogene proboscidean remains from Hungary; an overview. Fragm. Palaeontol. Hung. 19, 61-77.

Gasparik, M., Kele, S., 2010. Sedimentological and paleontological study and Uranium-series dating of the Tokod travertine paleovertebrate site (Eastern-Gerecse). Tatabányai Múzeum Évkönyve I 29-39, In Hungarian with English abstract.

Gibbard, P., Van Kolfschoten, T., 2005. The pleistocene and Holocene epochs. In: Gradstein, F.H., Ogg, J.G., Smith, A.G. (Eds.), A Geologic Time Scale 2004. Cambridge Univ. Press, pp. 441-452.

Gosse, J.C., Phillips, F.M., 2001. Terrestrial in situ cosmogenic nuclides: theory and application. Quat. Sci. Rev. 20, 1475-1560.

Granger, D.E., 2006. A review of burial dating methods using ${ }^{26} \mathrm{Al}$ and ${ }^{10} \mathrm{Be}$. In: In: Siame, L.L., Bourlès, D.L., Brown, E.T. (Eds.), In Situ-produced Cosmogenic Nuclides and Quantification of Geological Processes, vol. 415, Geological Society of America Special Papers, pp. 1-16.

Granger, D.E., Muzikar, P.F., 2001. Dating sediment burial with in situ-produced cosmogenic nuclides: theory, techniques, and limitations. Earth Planet Sci. Lett. 188, 269-281.

Guralnik, B., Matmon, A., Avni, Y., Porat, N., Fink, F., 2011. Constraining the evolution of river terraces with integrated OSL and cosmogenic nuclide data. Quat. Geochronol. 6 , 22-32.

Halaváts, Gy, 1898. The age of the gravels around Budapest. Foldtani Kozlony 28 , 291-299, in Hungarian.

Häuselmann, P., Granger, D., Jeannin, P.Y., Lauritzen, S.E., 2007. Abrupt glacial valley incision at 0.8 Ma dated from cave deposits in Switzerland. Geology 35, 143-146.

Hennig, G.J., Grün, R., Brunnacker, K., Pécsi, M., 1983. Th230/U234 sowie ESR alterbestimmungen einiger travertine in ungarn. Eiszeitalt. Ggw. 33, 7-19.

Hidy, A.J., Gosse, J.C., Pederson, J.L., Mattern, J.P., Finkel, R.C., 2010. A geologically constrained Monte Carlo approach to modeling exposure ages from profiles of cosmogenic nuclides: an example from Lees Ferry, Arizona. G-cubed 11, Q0AA10. https://doi.org/ 10.1029/2010GC003084.

Horváth, F., Dövényi, P., Szalay, , Royden, L.H., 1988. Subsidence, thermal and maturation history of the Great Hungarian Plain. In: Royden, L.H., Horváth, F. (Eds.), The Pannonian Basin. A Study in Basin Evolution. - Am. Assoc. Pet. Geol. Memoir. vol. 45, pp. 355-372.

Horváth, F., Cloetingh, S., 1996. Stress-induced late stage subsidence anomalies in the Pannonian basin. Tectonophysics 266, 287-300.

Huntley, D.J., Baril, M.R., 1997. The K content of the K-feldspars being measured in optical dating or in thermoluminescence dating. Ancient TL 15/1, 11-13.

Jánossy, D., 1986. Pleistocene Vertebrate Faunas of Hungary. Akadémiai Kiadó, Budapest, $208 \mathrm{p}$. 
Jánossy, D., 1990. Vertebrate fauna of site II. In: Kretzoi, M., Dobosi, V. (Eds.), Vértesszőlős - Site, Man and Culture. Budapest. pp. 187-230.

Jánossy, D., Krolopp, E., 1981. Die pleistozänen Schnecken und Vertebraten-Faunen von Süttő. Fragm. Mineral. Palaeontol. 10, 31-58.

Kaiser, M., 1997. A geomorphic evolution of the Transdanubian Mountains, Hungary. Z. Geomorph. N. F. Suppl.-Bd. 110, 1-14, Berlin-Stuttgart.

Kele, S., 2009. Study of Freshwater Limestones from the Carpathian Basin: Paleoclimatological and Sedimentological Implications. PhD Thesis Eötvös Loránd University, Hungary, 176.

Kiss, D., Ruszák, Zs, Szőts, G.K., 2014. VLF measurements in the Betlehem quarry. In: Kiss, D., Ruszák, Zs, Szőts, G.K. (Eds.), Fieldwork Report. Eötvös University, Budapest, pp. 26-32, In Hungarian.

Kiss, D., K. Szőcs, G., Ruszák, Z., Bereczki, L., Molnár, G., Timár, G., Fodor, L., Csillag, G., Lantos, Z., 2015. Mapping of buried River terraces on the kopite hill, Gerecse Mts., northern Hungary. EGU general assembly 2015. Vienna. Geophys. Res. Abstr. $17,13434$.

Kordos, L., 1994. Revised biostratigraphy of the early man site at Vértesszölös, Hungary. Cour. Forschungsinst. Senckenberg 171, 225-236.

Kormos, T., 1912. Paleolithic site of Tata. A Földtani Intézet Évkönyve 20, 1-66, in Hungarian.

Kretzoi, M., 1953. Quaternary Chronostratigraphy Based on the Vertebrate Fauna. Alföldi Kongresszus, Budapest, 89-97, in Hungarian).

Kretzoi, M., 1964. Die Wirbeltierfauna des Travertinkomplexes von Tata. In: Vértes, L. (Ed.), Tata eine Mittelpaläolithische Travertin-siedlung in Ungarn. Akadémiai Kiadó, Budapest, pp. 105-126.

Kretzoi, M., Dobosi, V.T. (Eds.), 1990. Vértesszőlős - Site, Man and Culture. Akadémiai Kiadó, Budapest, pp. 1-552.

Krolopp, E., 2004. The importance of mollusc fauna in the study of travertine deposits. Foldtani Kozlony 134/2, 219-225.

Krolopp, E., 1990. Molluscan fauna from Vértesszőlős. In: Kretzoi, M., Dobosi, V.T. (Eds.), Vértesszőlős - Site, Man and Culture. Akadémiai Kiadó, Budapest, pp. 163-182.

Krolopp, E., 1995. Biostratigraphic division of Pleistocene formations in Hungary according to their Mollusc fauna. In: Füköh, L. (Ed.), Quaternary Malacostratigraphy in Hungary. Malacological Newsletter, pp. 17-78, Suppl. 1.

Krolopp, E., 2014. Taxonomic, Faunistic, Stratigraphic and Paleoecological Evaluation of the Hungarian Pleistocene Mollusc Fauna. Malacological Newsletter 31. Mátra Museum of the Hungarian Natural History Museum, Gyöngyös, 1-73.

Lal, D., 1991. Cosmic ray labelling of erosion surfaces: in situ nuclide production rates and erosion rates. Earth Planet Sci. Lett. 104, 424-439.

Lantos, M., 2004. Magnetostratigraphic correlation of Quaternary travertine sequences in NE Transdanubia. Foldtani Kozlony 134/2, 227-236.

Latham, A.G., Schwarcz, H.P., 1990. Magnetic polarity of travertine samples from Vértesszőlős. -. In: Kretzoi, M., és Dobosi, V.T. (Eds.), Vértesszőlős - Site, Man and Culture. Akadémiai Kiadó, Budapest, pp. 553-555.

Lebatard, A.-E., Alçiçek, M.C., Rochette, P., Khatib, S., Vialet, A., Boulbes, N., Bourlés, D., Demory, F., Guipert, G., Mayda, S., Titov, V., Vidal, L., de Lumley, H., 2014. Dating the Homo erectus bearing travertine from Kocabas, (Denizli, Turkey) at least 1.1 Ma. Earth Planet Sci. Lett. 390, 8-18.

Lisiecki, L.E., Raymo, M.E., 2005. A Pliocene-Pleistocene stack of 57 globally distributed benthic $\mathrm{d}^{18} \mathrm{O}$ records. Paleoceanography 20, PA1003 https://doi.org/10.1029/ 2004PA001071.

van der Made, J., Aguirre, E., Bastir, M., Fernández-Jalvo, Y., Huguet, R., Laplana, C., Marquez, B., Martínez, C., Martinón, M., Rosas, A., Rodríguez, J., Sánchez, A., Sarmiento, S., Bermúdez de Castro, J.M., 2003. The paleontological and archaeological record of the localities of the Trinchera del Ferrocarril in the Sierra de Atapuerca. Coloquios Paleontol. 1, 345-372, in Spanish with English abstract.

van der Made, J., 2010. The rhinos from the middle pleistocene of Neumark-Nord (Saxony-Anhalt). Veröffentlichungen des Landesamtes für Denkmalpflege und Archäologie $62,433-500$.

van der Made, J., 2011. Biogeography and climatic change as a context to human dispersal out of Africa and within Eurasia. Quat. Sci. Rev. 30, 1353-1367.

van der Made, J., 2015. The rhinoceros Stephanorhinus aff. Etruscus from the latest early pleistocene of cueva Victoria (Murcia, Spain). Mastia 11-13, 359-383.

Mádl-Szőnyi, J., Tóth, , 2015. Basin-scale conceptual groundwater flow model for an unconfined and confined thick carbonate region. Hydrogeol. J. https://doi.org/10.1007/ s10040-015-1274-X.

Matsushi, Y., Wakasa, S., Matsuzaki, H., Matsukura, Y., 2006. Long-term denudation rates of actively uplifting hillcrests in the Boso Peninsula, Japan, estimated from depth profiling of in situ-produced cosmogenic ${ }^{10} \mathrm{Be}$ and ${ }^{26} \mathrm{Al}$. Geomorphology 82, 283-294.

Maul, L.C., Markova, A.K., 2007. Similarity and regional differences in quaternary arvicolid evolution in central and eastern Europe. Quat. Int. 160, 81-99.

Murray, A.S., Schmidt, E.D., Stevens, T., Buylaert, J.-P., Marković, S.B., Tsukamoto, S., Frechen, M., 2014. Dating Middle Pleistocene loess from Stari Slankamen (Vojvodina, Serbia) - limitations imposed by the saturation behaviour of an elevated temperature IRSL signal. Catena 117, 34-42.

Nishiizumi, K., Winterer, E.L., Kohl, C.P., Klein, J., Middleton, R., Lal, D., Arnold, J.R., 1989. Cosmic ray production rates of $10 \mathrm{Be}$ and $26 \mathrm{Al}$ in quartz from glacially polished rocks. J. Geophys. Res. 94, 17907-17915.

Novothny, A., Frechen, M., Horvath, E., Wacha, L., Rolf, C., 2011. Investigating the penultimate and last glacial cycles of the Süttő loess section (Hungary) using luminescence dating, high-resolution grain size, and magnetic susceptibility data. Quat. Int. 234, 75-85.
Olley, J.M., D. D, P., Roberts, R.G., Fifield, L.K., Yoshida, H., Hancock, G., 2004. Optical dating of deep-sea sediments using single grains of quartz: a comparison with radiocarbon. Sediment. Geol. 169, 175-189.

Osmond, J.K., 1990. Th ${ }^{230} / \mathrm{U}^{234}$ dating of Vértesszólős. In: Kretzoi, M., Dobosi, V. (Eds.), Vértesszólős - Site, Man and Culture. Budapest. p. 545.

Pazonyi, P., 2006. PhD Thesis Palaeoecological and Stratigraphical Investigations of the Quaternary Mammalian Communities in the Carpathian Basin, vol. 114, Eötvös University, Budapest, In Hungarian with English summary).

Pazonyi, P., 2011. Palaeoecology of late Pliocene and quaternary mammalian communities in the carpathian basin. Acta Zool. Cracoviensia - Ser. A Vertebr. 54 (1-2), 1-32.

Pazonyi, P., Kordos, L., Magyari, E., Marinova, E., Fükőh, L., Venczel, M., 2014. Pleistocene vertebrate faunas of the Süttô travertine complex (Hungary). Quat. Int. 319, $50-63$.

Pécsi, M., 1959. Formation and Geomorphology of the Danube Valley in Hungary (In Hungarian with German Summary). Akadémiai Kiadó, Budapest, 346.

Pécsi, M., 1973. Geomorphological position and absolute age of the lower paleolithic site at Vértesszólős, Hungary. Földrajzi Közlemények XXI, 109-125, Kötet.

Pécsi, M., Osmond, J.K., 1973. Geomorphological position and absolute age of the settlement at Vértesszólós of Lower Paleolithic prehistoric man in Hungary. In: 9th Congress Internat Union Quat. Res. Christchurch, Abstracts. pp. 283-284.

Pécsi, M., Scheuer, Gy, Schweitzer, F., 1982. Geomorphological position and chronological classification of Hungarian travertines. Quaternary Studies in Hungary 117-133, Budapest.

Pécsi, M., Scheuer, Gy, Schweitzer, F., 1984. Plio-Pleistocene tectonic movements and the travertine horizons in the Hungarian Mountains. Stud. Geomorphol. Carpatho-Balcanica 19-27.

Portenga, E.W., Bierman, P.R., 2011. Understanding Earth's eroding surface with ${ }^{10} \mathrm{Be}$ GSA Today (Geol. Soc. Am.) 21 (8), 4-10.

Prescott, J.R., Hutton, J.T., 1994. Cosmic ray contribution to dose rates for luminescence and ESR dating: large depths and long-term time variations. Radiat. Meas. 23, 497-500.

Prescott, J.R., Stephan, L.G., 1982. The contribution of cosmic radiation to the environmental dose for thermoluminescent dating. Latitude, altitude and depth dependences. PACT 6, 17-25.

Rihs, S., Condomines, M., Poidevin, J., 2000. Long-term behaviour of continental hy drothermal systems: U-series study of hydrothermal carbonates from the French Massif Central (Allier Valley). Geochem. Cosmochim. Acta 64, 3189-3199.

Rixhon, G., Braucher, R., Bourlès, D., Siame, L., Bovy, B., Demoulin, A., 2011. Quaternary river incision in NE Ardennes (Belgium)-Insights from ${ }^{10} \mathrm{Be} /{ }^{26} \mathrm{Al}$ dating of river terraces. Quat. Geochronol. 6, 273-284.

Rixhon, G., Bourlès, D., Braucher, R., Siame, L., Cordy, J.-M., Demoulin, A., 2014. ${ }^{10} \mathrm{Be}$ dating of the Main Terrace level in the Ambléve valley (Ardennes, Belgium): new age constraint on the archaeological and palaeontological filling of the Belle-Roche palaeokarst. Boreas 43 (2), 528-542.

Rixhon, G., Briant, R., Cordier, S., Duval, M., Jones, A., Scholz, D., 2017. Revealing the pace of river landscape evolution during the Quaternary: recent developments in numerical dating methods. Quat. Sci. Rev. 166, 91-113.

Ruszkiczay-Rüdiger, Zs, Bradák, B., 2005. Joint application of sedimentology and magnetic susceptibility in the study of the last interglacial, Tata-Porhanyóbánya, Hungary. Foldtani Kozlony 135/2, 193-208, with English abstract.

Ruszkiczay-Rüdiger, Zs, Fodor, L., Bada, G., Leél-Össy, Sz, Horváth, E., Dunai, T.J., 2005a. Quantification of Quaternary vertical movements in the central Pannonian Basin: a review of chronologic data along the Danube River, Hungary. Tectonophysics 410 (1-4), 157-172.

Ruszkiczay-Rüdiger, Zs, Dunai, T.J., Bada, G., Fodor, L., Horváth, E., 2005b. Middle to late pleistocene uplift rate of the Hungarian mountain range at the Danube bend (Pannonian Basin) using in situ produced ${ }^{3} \mathrm{He}$. Tectonophysics 410 (1-4), 173-187.

Ruszkiczay-Rüdiger, Zs, Fodor, L., Horváth, E., Telbisz, T., 2009. Discrimination of fluvial, eolian and neotectonic features in a low hilly landscape, a DEM-based morphotectonic analysis in the Central Pannonian Basin, Hungary. Geomorphology 104 (3-4), 203-217.

Ruszkiczay-Rüdiger, Zs, Braucher, R., Csillag, G., Fodor, L., Dunai, T.J., Bada, G., Bourlés, D., Müller, P., 2011. Dating pleistocene aeolian landforms in Hungary, Central Europe, using in situ produced cosmogenic ${ }^{10} \mathrm{Be}$. Quat. Geochronol. 6, 515-529.

Ruszkiczay-Rüdiger, Zs, Braucher, R., Novothny, , Csillag, G., Fodor, L., Molnár, G., Madarász, B., ASTER Team, 2016. Tectonic and climatic forcing on terrace formation: coupling in situ produced 10Be depth profiles and luminescence approach, Danube River, Hungary, Central Europe. Quat. Sci. Rev 131, 127-147.

Schaller, M., Ehlers, T.A., Stor, T., Torrent, J., Lobato, L., Christl, M., Vockenhuber, C., 2016. Timing of European fluvial terrace formation and incision rates constrained by cosmogenic nuclide dating. Earth Planet Sci. Lett. 451, 221-231.

Scheuer, Gy, 1997. Paleo-hydrological study on the freshwater limestone of the Csúcsos hill in the western Gerecse hills (in Hungarian). Hidrol. Tajekoztato 1997, oct. 23-26.

Scheuer, Gy, Schweitzer, F., 1988. Freshwater Limestones of the Gerecse and Buda Hills (In Hungarian). Földr. Tanulm, vol. 20, Akad. Kiadó, Budapest, 129.

Scholz, D., Tolzmann, J., Hoffmann, D.L., Jochum, K.P., Spötl, C., Riechelmann, D.F.C., 2014. Diagenesis of speleothems and its effect on the accuracy of $230 \mathrm{Th} / \mathrm{U}$-ages. Chem. Geol. 387, 74-86.

Schréter, Z., 1953. Les occurences de calcaire d'eau douce bords des montagnes de Buda et Gerecse. A MÁFI Évi Jelentése az 1951. évrôl. 111-150, (in Hungarian with French abstract).

Schulte, L., Julia, R., Burjachs, F., Hilgers, A., 2008. Middle Pleistocene to Holocene geochronology of the river Aguas terrace sequence (Iberian peninsula): fluvial response to mediterranean environmental change. Geomorphology 98 (1-2), 13-33. 
Z. Ruszkiczay-Rüdiger et al.

Quaternary Geochronology xxx (2018) xxx-xxx

Schwarcz, H.P., Skoflek, I., 1982. New dates for the Tata, Hungary archaeological site. Nature 295, 590-591.

Schwarcz, H.P., Latham, A.G., 1984. Uranium series age determination of travertines from the site of Vértesszőlôs, Hungary. J. Archaeol. Sci. 11, 327-336.

Schwarcz, H.P., Latham, A.G., 1990. Absolute age determination of travertines from the Vértesszőlős site. In: Kretzoi, M., Dobosi, V. (Eds.), Vértesszőloós - Site, Man and Culture. Budapest. pp. 549-552.

Schweitzer, F., Scheuer, Gy, 1995. Hungarian travertines. Acta Univ. Szegediensis, Acta Geographica 34, 163-186, Spec. Issue.

Scotti, V.N., Molin, P., Faccenna, C., Soligo, M., Casas-Sainz, A., 2014. The influence of surface and tectonic processes on landscape evolution of the Iberian Chain (Spain): quantitative geomorphological analysis and geochronology. Geomorphology 206, 37-57.

Siame, L., Bellier, O., Braucher, R., Sebrier, M., Cushing, M., Bourles, D.L., Hamelin, B., Baroux, E., de Voogd, B., Raisbeck, G., Yiou, F., 2004. Local erosion rates versus active tectonics: cosmic ray exposure modelling in Provence (South-East France). Earth Planet Sci. Lett. 220 (3-4), 345-364.

Sierralta, M., Kele, S., Melcher, F., Hambach, U., Reinders, J., Van Geldern, R., Frechen, M., 2010. Uranium-sereies dataing of travertine from Süttő: implications for reconstruction of environmental change in Hungary. Quat. Int. 222, 178-193.

Soligo, M., Tuccimei, P., Barberi, R., Delitala, M.C., Miccadei, E., Taddeucci, A., 2002. U/Th dating of freshwater travertine from Middle Velino Valley (Central Italy): paleoclimatic and geological implications. Palaeogeogr. Palaeochmatol. Palaeoecol. 184 (1-2), 147-161.

Stange, K.M., van Balen, R., Carcaillet, J., Vandenberghe, J., 2013. Terrace staircase development in the southern pyrenees foreland: inferences from ${ }^{10} \mathrm{Be}$ terrace exposure ages at the Segre River. Global Planet. Change 101, 97-112.

Stange, K.M., van Balen, R.T., Kasse, C., Vandenberghe, J., Carcaillet, J., 2014. Linking morphology across the glaciofluvial interface: $\mathrm{a}^{10} \mathrm{Be}$ supported chronology of glacier advances and terrace formation in the Garonne River, northern Pyrenees, France. Geomorphology 207, 71-95.

Thiel, C., Buylaert, J.-P., Murray, A.S., Terhorst, B., Hofer, I., Tsukamoto, S., Frechen, M., 2011. Luminescence dating of the Stratzing loess profile (Austria). - testing the potential of an elevated temperature post-IR IRSL protocol. Quat. Int. 234, 23-31.

Thiel, C., Buylaert, J.-P., Murray, A.S., Elmejdoub, N., 2012. A comparison of TT-OSL and post-IR IRSL dating of coastal deposits on Cap Bon peninsula, north-eastern Tunisia. Quat. Geochronol. 10, 209-217.

Thompson, J.A., Chen, J., Yang, H., Li, T., Bookhagen, B., Burbank, D., 2018. Coarse-versus fine-grain quartz OSL and cosmogenic ${ }^{10} \mathrm{Be}$ dating of deformed fluvial terraces on the northeast Pamir margin, northwest China. Quat. Geochronol. 46, 1-15.

Török, , Mindszenty, A., Claes, H., Fodor, L., Swennen, R., 2017. Geobody architecture of continental carbonates: "Gazda" travertine quarry (Süttô, Gerecse Hills, Hungary). Quat. Int. 437, 164-185.

Vasile, , Panaitescu, D., Ştiucă, E., Virág, A., 2012. Additional proboscidean fossils from Mavrodin (teleorman county, Romania). Oltenia, Studii şi comunicări. Seria Ştiinţele Naturii 28/2, 211-218.
Veldkamp, A., Kroonenberg, S., Heijnis, H., Van Den Berg Van Saparoea, R., 2004. The suitability of dated travertines as a record of fluvial incision: Allier (France) floodplain dynamics during the Late Quaternary. Quaternaire 15 (1-2), 159-165.

Vermeesch, P., 2012. On the visualisation of detrital age distributions. Chem. Geol. 312-313, 190-194.

Vértes L., Tata - eine mittelpaläolitische Travertin-Siedlung in Ungarn. In: ArchHung 43, 1964. 1-285.

Viczián, I., 2013. The gravel sequence and travertines of the Betlehem quarry (Dunaalmás). (In Hungarian). In: Kis, É. (Ed.), Terresztrikus Domborzatfejlődés a Vértes És a Gerecse Környezetében a Bérbaltaváriumtól a Holocénig. MTA CsFK Földrajztudományi Intézet, Budapest, pp. 73-79.

Virág, A., 2013. Morphometrical and Palaeoecological Study of Hungarian Pliocene and Pleistocene Elephantides. PhD Thesis. Eötvös University, Budapest, 146, (In Hungarian with English summary).

Virág, A., Gasparik, M., 2012. Relative chronology of late Pliocene and early pleistocene mammoth bearing localities in Hungary. Hantkeniana 7, 27-36.

Viveen, W., Braucher, R., Bourlés, D., Schoorl, J.M., Veldkamp, A., van Balen, R.T., Wallinga, Fernandez-Mosquera, D., Vidal-Romani, J.R., Sanjurjo-Sanchez, J., 2012. A 0.65 Ma chronology and incision rate assessment of the NW Iberian Miño River terraces based on ${ }^{10} \mathrm{Be}$ and luminescence dating. Global Planet. Change 94-95, 82-100.

Wagner, T., Fabel, D., Fiebig, M., H€auselmann, P., Sahy, D., Xu, S., Stüwe, K., 2010. Young uplift in the non-glaciated parts of the Eastern Alps. Earth Planet Sci. Lett. 295, 159-169.

Wang, Z., Meyer, M.C., Gliganic, L.A., Hoffmann, D.L., May, J.-H., 2017. Timing of fluvial terrace formation and concomitant travertine deposition in the upper Sutlej River (Tirthapuri, southwestern Tibet) and paleoclimatic implications. Quat. Sci. Rev. 169, 357-377.

Ward, G.K., Wilson, S.R., 1978. Procedures for comparing and combining radiocarbon age-determinations - critique. Archaeometry 20, 19-31.

Wintle, A., Murray, A.S., 2006. A review of quartz optically stimulated luminescence characteristics and their relevance in single-aliquot regeneration dating protocols. Radiat. Meas. 41, 369-391.

Wüthrich, L., Brändli, C., Braucher, R., Veit, H., Haghipour, N., Terrizzano, C., Christl, M., Gnägi, C., Zech, R., 2017. Be depth profiles in glacial sediments on the Swiss Plateau: deposition age, denudation and (pseudo-) inheritance. E\&G Quaternary Sci. J. 66, 57-68.

Zentmyer, R., Myrow, P.M., Newell, D.L., 2008. Travertine deposits from along the south Tibetan fault system near Nyalam. Tibet. Geol. Mag. 145 (6), 753-765.

Zhao, Z., Granger, D., Zhang, M., Kong, X., Yang, S., Chen, Y., Hu, E., 2016. A test of the isochron burial dating method on fluvial gravels within the Pulu volcanic sequence, West Kunlun Mountains, China. Quat. Geochronol. 34, 75-80.

24 